
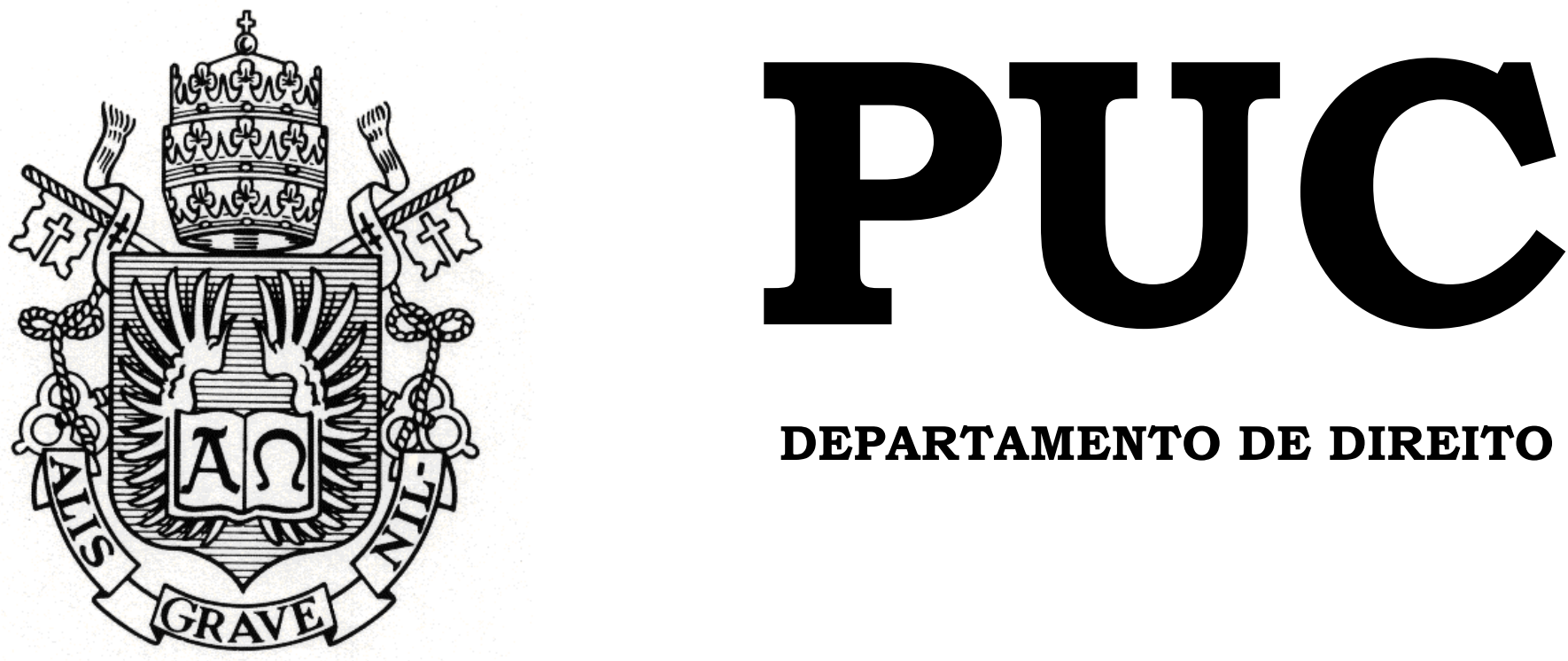

DEPARTAMENTO DE DIREITO

\title{
A JUDICIALIZAÇÃO DO DIREITO À SAÚDE
}

por

ALINE PINHO DA COSTA VAL

ORIENTADORA: Regina Coeli Lisbôa Soares

2019.1

PONTIFÍCIA UNIVERSIDADE CATÓLICA DO RIO DE JANEIRO

RUA MARQUÊS DE SÃO VICENTE, 225 - CEP 22453-900

RIO DE JANEIRO - BRASIL 


\section{A JUDICIALIZAÇÃO DO DIREITO À SAÚDE}

por

\section{ALINE PINHO DA COSTA VAL}

Monografia

apresentada

ao

Departamento de Direito da Pontificia Universidade Católica do Rio de Janeiro (PUC-Rio) para a obtenção do Título de Bacharel em Direito.

Orientadora: Regina Coeli Lisbôa Soares 
"Não é sinal de saúde estar bem ajustado a uma sociedade profundamente doente." (J. Krishnamurti) 


\section{Agradecimentos}

Agradeço ao meu pai, Hermano, um anjo, que conduziu meu caminho até o curso de Direito, com o qual me identifico imensamente. Onde você estiver, sei que está vibrando com as minhas conquistas!

Meu eterno agradecimento à minha mãe Denise, à minha família e ao meu namorado, que sempre me apoiaram e vibraram com todas as minhas conquistas e, nos momentos difíceis, estiveram presentes.

Agradeço aos amigos que fiz ao longo da faculdade e que tornaram esses cinco anos, sem dúvidas, uns dos melhores da minha vida. Em especial, Carolina Abreu, minha grande amiga, companheira de iniciação científica e dupla inseparável; Isabella Rehder, minha colega de estágio com que compartilhei dificuldades e aprendizados; Louise Fonseca, Mariana Gianotti e Mariana Gagliano que sempre dividiram os momentos de angústia antes das provas e também os momentos de diversão e; Tatiane Souza que sempre foi fonte de inspiração.

A todos os brilhantes professores da PUC-RIO, que me fizeram amadurecer profissionalmente e pessoalmente. Em especial, ao professor Fábio Leite que confiou em mim e me deu a oportunidade de participar do projeto de iniciação científica, fazendo com que eu me apaixonasse cada vez mais pelo Direito Constitucional.

Por fim, todo o meu agradecimento e admiração à minha orientadora, a brilhante professora Regina Coeli, que, por meio de suas aulas, despertou meu interesse por Direito Constitucional e, mais do que isso, me fez perceber que o Direito é um instrumento de transformação social. Continuaremos na luta! 
Resumo

O presente trabalho busca analisar o direito fundamental à saúde sob diferentes óticas com a finalidade de compreender o fenômeno da judicialização desse direito. Para isso, remonta à origem histórica do direito à saúde, explica porque foi concedida proteção especial a ele no ordenamento jurídico brasileiro, destaca o papel do Poder Judiciário como concretizador da Constituição Federal de 1988 e as dificuldades que permeiam a sua atuação como, por exemplo, a limitação orçamentária do Estado. Nesse contexto, apresenta medidas para a efetivação do direito à saúde que perpassam iniciativas que visam a prevenção dos conflitos, o aperfeiçoamento e a maior eficiência das decisões judiciais nas demandas que envolvem o direito à saúde e revisita os Conselhos de Saúde, que passam a ser vistos como instrumentos de governança.

\section{Palavras-Chave}

Direito Constitucional. Direito à Saúde. Judicialização. Políticas Públicas. 


\section{Sumário}

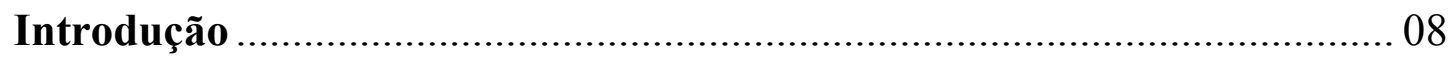

Capítulo I - O Direito Fundamental à Saúde ........................................... 10

1.1 A pessoa humana e seus direitos ....................................................... 12

$1.2 \mathrm{O}$ reconhecimento dos direitos humanos de caráter econômico e sociais 16

1.3 Posição dos direitos humanos no sistema normativo................................ 18

Capítulo II - A positivação do Direito à Saúde ……………………............ 22

2.1 O Direito à Saúde na Constituição Federal de 1988 ................................. 23

2.2 O Direito à Saúde na legislação infraconstitucional: a Lei do SUS, o

Estatuto do Idoso e o Estatuto da Criança e do Adolescente......................... 26

Capítulo III - A efetivação do direito à saúde mediante a intervenção do

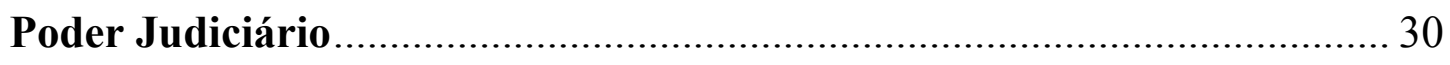

3.1 Princípio do mínimo existencial versus princípio da reserva do possível .

3.2 Violação ao Princípio da Equidade? ........................................................ 37

3.3 A independência do Poder Executivo: respeito às políticas públicas ..... 41

3.3.1 Parâmetros de Controle das Políticas Públicas ..................................... 42

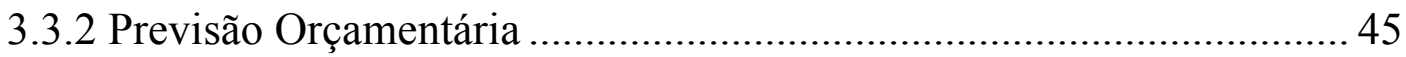

3.3.3 Orçamento Participativo …………………......................................... 49 
Capítulo IV - Medidas para a efetivação do Direito à Saúde ...................... 52

4.1 Núcleos de Assessoramento Técnico (NAT) ………..............................54

4.2 Câmara de Resolução de Litígios de Saúde .............................................. 57

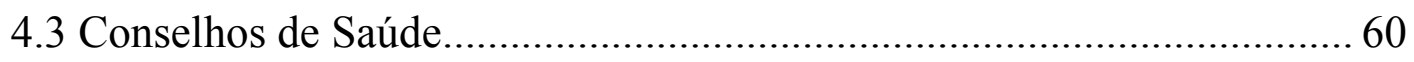

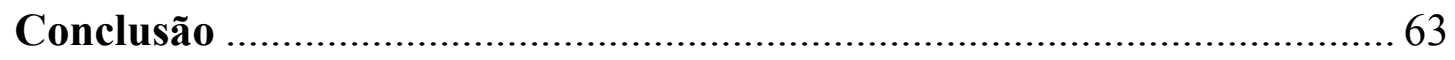

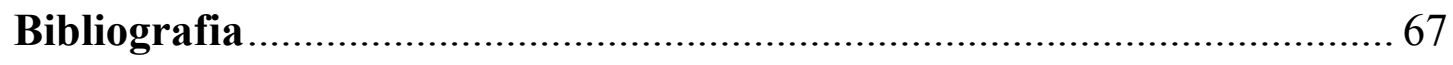




\section{Lista de Abreviações}

$\S$ - Parágrafo

Art. - Artigo

CF - Constituição da República Federativa de 1988

CNJ - Conselho Nacional de Justiça

Ed. - Edição

Min. - Ministro

NAT - Núcleo de Assessoramento Técnico

ONU - Organização das Nações Unidas

p. - Página

$\mathrm{n}^{\mathrm{o}}-$ Número

Rel. - Relator (a)

RE - Recurso Extraordinário

STF - Supremo Tribunal Federal

SUS- Sistema Único de Saúde

Vol. - Volume 


\section{Introdução}

O presente trabalho busca analisar o direito fundamental à saúde sob diferentes óticas com a finalidade de compreender o fenômeno da judicialização desse direito.

Para tanto, no Capítulo I é traçado um histórico do direito fundamental à saúde e é apresentada a sua definição, sob a perspectiva de que se trata de um direito social, ou seja, envolve um aprofundamento da justiça social na medida em que corresponde a algumas das reivindicações das classes menos favorecidas e visa assegurar um mínimo existencial. ${ }^{1}$

Já o Capítulo II situa esse direito no ordenamento jurídico brasileiro com destaque para a sua proteção especial, prevista na Constituição Federal de 1988, que consagrou o direito à saúde como direito de todos e dever do Estado, garantido mediante políticas sociais e econômicas que visem à redução do risco de doença e de outros agravos e ao acesso universal e igualitário às ações e serviços para a sua promoção, proteção e recuperação, nos termos do art. $196 .{ }^{2}$

No capítulo III, apresenta-se sob qual argumentação se dá a tutela do direito à saúde por meio do Poder Judiciário, que passa a "ter papel decisivo na concretização da Constituição". Assim, aborda-se de forma mais detalhada: o “conflito" entre princípio do mínimo existencial e o princípio da reserva do possível; a violação ao princípio da equidade quando o Poder Judiciário ignora que não há recursos suficientes para se implementar o direito fundamental universalmente de forma ilimitada e deixa de atentar para as políticas públicas já existentes e; a independência do Poder Executivo na elaboração do orçamento e das políticas públicas. Nesse contexto, é indicada a alternativa do

\footnotetext{
${ }^{1}$ SARLET, Ingo Wolfang. A eficácia dos direitos fundamentais: uma teoria geral dos direitos fundamentais na perspectiva constitucional/ Ingo Wolfang Sarlet. $11^{\mathrm{a}}$ ed. rev. atual. Porto Alegre: Livraria do Advogado Editora, 2012. p. 33.

${ }^{2}$ SILVA, José Afonso da. Curso de direito constitucional positivo-38 ${ }^{\mathrm{a}}$ ed. revista e atualizada. São Paulo: Malheiros Editores Ltda., 2014, p. 312
} 
Orçamento Participativo como forma de permitir a alocação dos recursos para garantir "todo o conjunto de prestações materiais indispensáveis para assegurar a cada pessoa uma vida condigna, no sentido de vida saudável”3, inviabilizando a invocação da reserva do possível pelo Estado com o intuito de se eximir da promoção dos direitos que compõem o mínimo existencial.

O capítulo IV, por sua vez, aborda medidas para a efetivação do direito à saúde. Assim, apresenta iniciativas que visam a prevenção dos conflitos, o aperfeiçoamento e a maior eficiência das decisões judiciais nas demandas que envolvem o direito à saúde. São iniciativas apresentadas os Núcleos de Assessoramento Técnico e as Câmaras de Resolução de Litígios de Saúde. Ainda revisita os Conselhos de Saúde, que apesar de já existirem no país desde os anos 90, passam a ser vistos como instrumentos de social accountability ${ }^{4}$.

Dessa forma, pretende-se retratar os instrumentos disponíveis para a efetivação do direito à saúde de forma mais plena possível, sem deixar de lado as limitações fáticas existentes como, por exemplo, a limitação do orçamento. Isso, porque, dessa forma é preservada a capacidade do estado de sustentar as suas políticas públicas, o que é prejudicado pela "indústria da judicialização".

\footnotetext{
${ }^{3}$ SARLET, I.; FIGUEIREDO, M. Reserva do possível, mínimo existencial e direito à saúde. Revista Brasileira de Direitos Fundamentais \& Justiça, v. 1, n. 1, p. 171-213, 25 mar. 2007. p. 184. Disponível em: < http://dfj.emnuvens.com.br/dfj/article/view/590>. Acesso em: 12.04.2019.

${ }^{4} \mathrm{O}$ termo "Social Accountability" é utilizado para se referir à responsabilização por controle social. ${ }^{5}$ OLIVEIRA, Valdir de Castro. Comunicação, informação e participação popular nos Conselhos de Saúde. Saude soc., São Paulo, v. 13, n. 2, p. 56-69, ago. 2004. p.63. Disponível em $<$ http://www.scielo.br/scielo.php?script=sci_arttext\&pid=S010412902004000200006\&lng=pt\&nrm=io >. Acesso em 18.05.2019.
} 


\section{Capítulo I- O Direito Fundamental à Saúde}

O direito à saúde, contemporaneamente, é considerado um direito fundamental pois é pautado no princípio de que todos seres humanos têm igual direito à vida. De acordo com ele, as pessoas precisam ter acesso a todas as prestações necessárias para preservar, manter ou reestabelecer a sua saúde. ${ }^{6}$ Assim, coaduna-se como a possibilidade de, em caso de doença, cada um ter um tratamento condizente com o estado atual da ciência médica, independente da sua situação econômica. ${ }^{7}$

De acordo com José Afonso da Silva ${ }^{8}$, a Constituição Italiana, em seu artigo 32, foi a primeira carta a reconhecer a saúde como direito fundamental do indivíduo e de interesse da coletividade. Veja:

“Art. 32. A República tutela a saúde como direito fundamental do indivíduo e interesse da coletividade, e garante tratamentos gratuitos aos indigentes. Ninguém pode ser obrigado a um determinado tratamento sanitário, salvo disposição de lei. A lei não pode, em hipótese alguma, violar os limites impostos pelo respeito à pessoa humana."9

Posteriormente, de acordo com o doutrinador, a Constituição Portuguesa, em seu artigo $64^{\circ}$, teria logrado dar uma formulação universal mais precisa para o direito à saúde. ${ }^{10}$ Observe:

"Artigo 64"

Saúde

1. Todos têm direito à proteção da saúde e o dever de a defender e promover.

${ }^{6}$ BARCELLOS, Ana Paula de. A eficácia jurídica dos princípios constitucionais: O princípio da dignidade da pessoa humana. $-3^{\text {a }}$ ed. revista e atualizada. -Rio de Janeiro: Renovar, 2011, p. 320.

${ }^{7}$ SILVA, José Afonso da. Curso de direito constitucional positivo-38 ${ }^{\mathrm{a}}$ ed. revista e atualizada.-São Paulo: Malheiros Editores Ltda., 2014, p. 311.

${ }^{8}$ SILVA, José Afonso da. Curso de direito constitucional positivo-38 a ed. revista e atualizada.-São Paulo: Malheiros Editores Ltda., 2014, p. 312.

${ }^{9}$ Constituição da República Italiana de 22 de dezembro de 1947. Disponível em: $<$ https://www.senato.it/application/xmanager/projects/leg18/file/repository/relazioni/libreria/novita/X VII/COST_PORTOGHESE.pdf $>$. Acesso em: 03.06.2018.

${ }^{10}$ SILVA, José Afonso da. Curso de direito constitucional positivo- $38^{\mathrm{a}}$ ed. revista e atualizada.-São Paulo: Malheiros Editores Ltda., 2014, p. 312 
2. O direito à proteção da saúde é realizado:

a) Através de um serviço nacional de saúde universal e geral e, tendo em conta as condições económicas e sociais dos cidadãos, tendencialmente gratuito;

b) Pela criação de condições económicas, sociais, culturais e ambientais que garantam, designadamente, a proteção da infância, da juventude e da velhice, e pela melhoria sistemática das condições de vida e de trabalho, bem como pela promoção da cultura física e desportiva, escolar e popular, e ainda pelo desenvolvimento da educação sanitária do povo e de práticas de vida saudável.

3. Para assegurar o direito à proteção da saúde, incumbe prioritariamente ao Estado:

a) Garantir o acesso de todos os cidadãos, independentemente da sua condição económica, aos cuidados da medicina preventiva, curativa e de reabilitação;

b) Garantir uma racional e eficiente cobertura de todo o país em recursos humanos e unidades de saúde;

c) Orientar a sua ação para a socialização dos custos dos cuidados médicos e medicamentosos;

d) Disciplinar e fiscalizar as formas empresariais e privadas da medicina, articulandoas com o serviço nacional de saúde, por forma a assegurar, nas instituições de saúde públicas e privadas, adequados padrões de eficiência e de qualidade;

e) Disciplinar e controlar a produção, a distribuição, a comercialização e o uso dos produtos químicos, biológicos e farmacêuticos e outros meios de tratamento e diagnóstico;

f) Estabelecer políticas de prevenção e tratamento da toxicodependência.

4. O serviço nacional de saúde tem gestão descentralizada e participada."11

Note-se que ambas constituições relacionam o direito à saúde com a seguridade social e influenciaram a Constituição Brasileira de 1988 que, por sua vez, em seu artigo 196, considera "a saúde direito de todos e dever do Estado, garantido mediante políticas sociais e econômicas que visem à redução do risco de doença e de outros agravos e ao acesso universal e igualitário às ações e serviços para a sua promoção, proteção e recuperação". A partir da análise do dispositivo constitucional torna-se nítido que os poderes constituídos são obrigados a colocar à disposição das pessoas as prestações relacionadas à prevenção, manutenção e reestabelecimento da saúde, seja qual for o plano de governo ou orientação política do grupo que estiver no poder. ${ }^{12}$

Nesse contexto, com base na concepção adotada pela Constituição de 1988 pode-se observar que direito à saúde comporta duas vertentes: uma que

\footnotetext{
${ }^{11}$ Constituição da República Portuguesa de 25 de abril de 1974. Disponível em: $<$ http://www.parlamento.pt/Legislacao/Paginas/ConstituicaorepublicaPortuguesa.aspx $>$. Acesso em: 03.06.2018.

${ }^{12}$ BARCELlOS, Ana Paula de. A eficácia jurídica dos princípios constitucionais: O princípio da dignidade da pessoa humana. $-3^{\text {a }}$ ed. Revista e atualizada. -Rio de Janeiro: Renovar, 2011, p. 320.
} 
permite exigir do Estado ou terceiros que se abstenham de qualquer ato que prejudique a saúde; outra de natureza positiva que impõe ao Estado tomar medidas que previnam as doenças e permitam o seu tratamento. Isso possibilita que o Judiciário determine o fornecimento da prestação da saúde com base na Constituição, independente de existir uma ação específica da Administração ou do Legislativo nesse sentido.

Diante disso, cabe examinar a seguir, de forma minuciosa, como o direito à saúde foi alçado à posição de direito fundamental e como o Estado deve agir de forma a assegurar a sua observância. Não podemos deixar de lado nessa análise a dificuldade que os magistrados encontram quando se deparam com "um doente com rosto, identidade, presença física e história" 13 pleiteando em juízo uma prestação de saúde não incluída no mínimo existencial ou autorizada por lei, mas da qual depende para a sua sobrevivência. ${ }^{14}$

\subsection{A pessoa humana e seus direitos}

A noção de que todos os homens possuem uma igualdade essencial surge no período axial da História. ${ }^{15}$ Não obstante, apenas vinte e cinco séculos depois, a Declaração Universal dos Direitos Humanos proclamou que "os seres humanos nascem livres e iguais em dignidade e direitos". ${ }^{16}$

De acordo com Fabio Konder Comparato, a convicção de que os seres humanos têm direito a serem igualmente respeitados está relacionada ao fato da humanidade estar atrelada a uma instituição social que assume importância

\footnotetext{
${ }^{13}$ BARCELlos, Ana Paula de. A eficácia jurídica dos princípios constitucionais: O princípio da dignidade da pessoa humana. $-3^{\mathrm{a}}$ ed. Revista e atualizada. -Rio de Janeiro: Renovar, 2011, p. 322.

${ }^{14}$ BARCELLOS, Ana Paula de. A eficácia jurídica dos princípios constitucionais: O princípio da dignidade da pessoa humana. $-3^{\mathrm{a}}$ ed. Revista e atualizada. -Rio de Janeiro: Renovar, 2011, p. 322.

${ }^{15}$ COMPARATO, Fábio Konder. A afirmação histórica dos direitos humanos/ Fábio Konder Comparato.-4a ed. rev. e atual.-São Paulo: Saraiva, 2005, p.12.

${ }^{16}$ COMPARATO, Fábio Konder. A afirmação histórica dos direitos humanos/ Fábio Konder Comparato.- $4^{a}$ ed. rev. e atual.-São Paulo: Saraiva, 2005, p.12.
} 
ímpar: a lei escrita. ${ }^{17}$

A lei escrita, fundamento da sociedade política grega, surge como norma geral imposta a todos os indivíduos de forma uniforme que visa organizar a sociedade. ${ }^{18}$ Ela se apresenta como antídoto contra o arbítrio governamental, na medida que permite que os "fracos e ricos" gozem de um direito igual, e disponham de iguais meios para impor a sua observância. ${ }^{19}$

Não se pode, no entanto, deixar de lado a importância que as "leis não escritas" desempenharam. Os costumes juridicamente relevantes, as leis universais, regras jurídicas gerais e absolutas, que nascem com caráter essencialmente religioso, progressivamente, vão se desprendendo do misticismo. ${ }^{20}$ Nesse contexto, os autores gregos começaram a expressar a igualdade essencial do homem mediante a oposição entre a individualidade própria de cada homem e as funções ou atividades por eles desempenhadas na vida social, o que foi denominado com o termo personalidade. ${ }^{21}$

A "personalidade" foi objeto de estudo dos estoicos que se organizaram em torno da ideia de unidade moral do ser humano e da dignidade do homem. ${ }^{22}$ De acordo com eles, o ser humano possuiria direitos inatos e iguais em todas as partes do mundo independente de suas diferenças individuais e grupais. ${ }^{23}$

Ainda no período Medieval, no início do século VI, Boécio cunhou a seguinte definição de pessoa: "diz-se propriamente a pessoa a especificação

\footnotetext{
${ }^{17}$ COMPARATO, Fábio Konder. A afirmação histórica dos direitos humanos/ Fábio Konder Comparato.- $4^{a}$ ed. rev. e atual.-São Paulo: Saraiva, 2005, p.12.

${ }^{18}$ COMPARATO, Fábio Konder. A afirmação histórica dos direitos humanos/ Fábio Konder Comparato.- $4^{\text {a }}$ ed. rev. e atual.-São Paulo: Saraiva, 2005, p.12.

${ }^{19}$ COMPARATO, Fábio Konder. A afirmação histórica dos direitos humanos/ Fábio Konder Comparato.- $4^{a}$ ed. rev. e atual.-São Paulo: Saraiva, 2005, p.50.

${ }^{20}$ COMPARATO, Fábio Konder. A afirmação histórica dos direitos humanos/ Fábio Konder Comparato.- $4^{a}$ ed. rev. e atual.-São Paulo: Saraiva, 2005, p.14.

${ }^{21}$ COMPARATO, Fábio Konder. A afirmação histórica dos direitos humanos/ Fábio Konder Comparato.- $4^{a}$ ed. rev. e atual.-São Paulo: Saraiva, 2005, p.15.

${ }^{22}$ COMPARATO, Fábio Konder. A afirmação histórica dos direitos humanos/ Fábio Konder Comparato.- $4^{a}$ ed. rev. e atual.-São Paulo: Saraiva, 2005, p.16.

${ }^{23}$ COMPARATO, Fábio Konder. A afirmação histórica dos direitos humanos/ Fábio Konder Comparato.- $4^{a}$ ed. rev. e atual.-São Paulo: Saraiva, 2005, p.16.
} 
individual da substância racional” ${ }^{24}$. Assim, consolidou o entendimento de que a pessoa já não é uma exterioridade e sim a substância do homem, o que dá forma a ele. ${ }^{25}$

Conclui-se, assim, que sob a concepção medieval de pessoa, começou a ser construído o princípio da igualdade essencial de todo ser humano, ainda que consideradas as diferenças individuais ou grupais, de ordem biológica ou cultural $^{26}$. A igualdade cunhada nesse contexto, referente a essência da pessoa, forma o núcleo do conceito universal dos direitos humanos, expressão que se refere aos direitos comuns a toda espécie humana, a todo homem como tal, resultando de sua natureza, não sendo fruto de criação política. ${ }^{27} \mathrm{~A}$ partir do reconhecimento da igualdade entre os homens, foi possível concluir que toda as leis contrárias ao direito natural não teriam força jurídica. ${ }^{28}$

Ainda, contribuiu para a formação do conceito de pessoa como sujeito de direitos universais, a filosofia kantiana. ${ }^{29}$ De acordo com ela, a dignidade da pessoa não se baseia simplesmente no fato dela ser diferente das coisas, um fim tratado em si mesmo, mas também na possibilidade do homem viver em condições de autonomia por meio de sua vontade racional, ou seja, só ele pode guiar-se pelas leis que edita. ${ }^{30}$ Logo, quando se trata a pessoa como fim em si mesmo, é criado o dever negativo de não prejudicar ninguém e o dever positivo de atuar em prol da felicidade alheia, que legitima o reconhecimento dos direitos e liberdades individuais e "também dos direitos humanos à

\footnotetext{
${ }^{24}$ BOÉCIO, apud COMPARATO, Fábio Konder. A afirmação histórica dos direitos humanos/ Fábio Konder Comparato.- $4^{a}$ ed. rev. e atual.-São Paulo: Saraiva, 2005, p.19.

${ }^{25}$ COMPARATO, Fábio Konder. A afirmação histórica dos direitos humanos/ Fábio Konder Comparato.- $4^{a}$ ed. rev. e atual.-São Paulo: Saraiva, 2005, p.19.

${ }^{26}$ COMPARATO, Fábio Konder. A afirmação histórica dos direitos humanos/ Fábio Konder Comparato.-4a ed. rev. e atual.-São Paulo: Saraiva, 2005, p.20.

${ }^{27}$ COMPARATO, Fábio Konder. A afirmação histórica dos direitos humanos/ Fábio Konder Comparato.-4a ed. rev. e atual.-São Paulo: Saraiva, 2005, p.20.

${ }^{28}$ COMPARATO, Fábio Konder. A afirmação histórica dos direitos humanos/ Fábio Konder Comparato.-4a ed. rev. e atual.-São Paulo: Saraiva, 2005, p.20.

${ }^{29}$ COMPARATO, Fábio Konder. A afirmação histórica dos direitos humanos/ Fábio Konder Comparato.-4a ed. rev. e atual.-São Paulo: Saraiva, 2005, p.20.

${ }^{30}$ COMPARATO, Fábio Konder. A afirmação histórica dos direitos humanos/ Fábio Konder Comparato.-4a ed. rev. e atual.-São Paulo: Saraiva, 2005, p.21.
} 
realização de políticas públicas de conteúdo econômico e social, tal como enunciado nos artigos XXII a XVII da Declaração Universal dos Direitos Humanos". 31

Reconhece-se, portanto, que o homem é o único ser vivo que rege a sua vida em função de preferências valorativas. ${ }^{32}$ Assim, ele assume o papel de legislador em razão dos valores éticos que aprecia e como sujeito que se submete às normas valorativas. ${ }^{33}$

Por fim, a última etapa na elaboração do conceito de pessoa relaciona-se ao pensamento existencialista e à filosofia da vida. ${ }^{34}$ As convicções de que o homem é essencialmente racional, de que se molda conforme o ambiente social ao qual é submetido e de que não é permanente e imutável embasam a perspectiva da historicidade dos direitos humanos. ${ }^{35}$ Assim, cai por terra o que defendem os partidários do positivismo, que fora do Estado não existe direito. ${ }^{36}$ Corroborando essa tese, a Declaração Universal dos Direitos Humanos, em seu art. VI, determina que todo homem tem direito de ser, em todos os lugares, reconhecido como pessoa. ${ }^{37}$

\footnotetext{
${ }^{31}$ COMPARATO, Fábio Konder. A afirmação histórica dos direitos humanos/ Fábio Konder Comparato.- $4^{\mathrm{a}}$ ed. rev. e atual.-São Paulo: Saraiva, 2005, p.24.

${ }^{32}$ COMPARATO, Fábio Konder. A afirmação histórica dos direitos humanos/ Fábio Konder Comparato.- $4^{\mathrm{a}}$ ed. rev. e atual.-São Paulo: Saraiva, 2005, p.25.

${ }^{33}$ COMPARATO, Fábio Konder. A afirmação histórica dos direitos humanos/ Fábio Konder Comparato.- $4^{a}$ ed. rev. e atual.-São Paulo: Saraiva, 2005, p.25.

${ }^{34}$ COMPARATO, Fábio Konder. A afirmação histórica dos direitos humanos/ Fábio Konder Comparato.- $4^{a}$ ed. rev. e atual.-São Paulo: Saraiva, 2005, p.27.

${ }^{35}$ COMPARATO, Fábio Konder. A afirmação histórica dos direitos humanos/ Fábio Konder Comparato.-4a ed. rev. e atual.-São Paulo: Saraiva, 2005, p.32.

${ }^{36}$ COMPARATO, Fábio Konder. A afirmação histórica dos direitos humanos/ Fábio Konder Comparato.- $4^{a}$ ed. rev. e atual.-São Paulo: Saraiva, 2005, p.32.

${ }^{37}$ COMPARATO, Fábio Konder. A afirmação histórica dos direitos humanos/ Fábio Konder Comparato.- $4^{\text {a }}$ ed. rev. e atual.-São Paulo: Saraiva, 2005, p.32.
} 


\subsection{0 reconhecimento dos direitos humanos de caráter econômico e sociais}

O homem, progressivamente, se emancipou historicamente dos grupos sociais a que pertencia, tais como a religião, a família e os clãs. ${ }^{38}$ Representam essa emancipação a Declaração de Direitos Norte-Americana e a Declaração Francesa de $1789 .^{39}$

Nesse contexto, o homem foi lançado em uma sociedade liberal que ofereceu, em troca da proteção religiosa, familiar e estamental uma garantia de igualdade de todos perante a lei. ${ }^{40}$ No entanto, essa igualdade de todos perante a lei revelou-se inútil diante da realidade enfrentada pelos trabalhadores, que eram praticamente obrigados a vender a sua força de trabalho, eram explorados pelos patrões, os detentores dos meios de produção. ${ }^{41}$ Não era viável falar em igualdade quando a realidade vivida pelos operários era muito distinta da dos seus contratantes.

Diante disso, no decorrer no século XIX, com o afloramento das doutrinas socialistas, surgiram movimentos reivindicatórios e o reconhecimento progressivo de direitos, atribuindo ao Estado comportamento ativo na realização da justiça social. ${ }^{42}$ Esses direitos, ressalta-se, tinham dimensão positiva, ou seja, não se cuidava mais de evitar a intervenção do Estado na esfera de liberdade individual, mas sim da liberdade por intermédio

\footnotetext{
${ }^{38}$ COMPARATO, Fábio Konder. A afirmação histórica dos direitos humanos/ Fábio Konder Comparato.-4a ed. rev. e atual.-São Paulo: Saraiva, 2005, p.52.

${ }^{39}$ COMPARATO, Fábio Konder. A afirmação histórica dos direitos humanos/ Fábio Konder Comparato.- $4^{\mathrm{a}}$ ed. rev. e atual.-São Paulo: Saraiva, 2005, p.52.

${ }^{40}$ COMPARATO, Fábio Konder. A afirmação histórica dos direitos humanos/ Fábio Konder Comparato.- $4^{a}$ ed. rev. e atual.-São Paulo: Saraiva, 2005, p.52.

${ }^{41}$ COMPARATO, Fábio Konder. A afirmação histórica dos direitos humanos/ Fábio Konder Comparato.- $4^{\mathrm{a}}$ ed. rev. e atual.-São Paulo: Saraiva, 2005, p.52.

${ }^{42}$ SARLET, Ingo Wolfang. A eficácia dos direitos fundamentais: uma teoria geral dos direitos fundamentais na perspectiva constitucional/ Ingo Wolfang Sarlet. $11^{\mathrm{a}}$ ed. rev. atual. Porto Alegre: Livraria do Advogado Editora, 2012. p. 32.
} 
do Estado. ${ }^{43}$

Esses direitos que exigem a prestação positiva do estado já haviam sido reconhecidos de forma isolada e primária nas Constituições Francesas de 1793 e 1848, na Constituição Brasileira de 1824 e na Constituição Alemã de $1848 .^{44}$ Eles têm como marca a outorga ao indivíduo de direitos a prestações estatais como a assistência social, saúde, educação, trabalho, dentre outras.

No entanto, apenas no século XX, especialmente nas Constituições do segundo pós-guerra, esses direitos fundamentais foram reconhecidos. De acordo com Fábio Konder Comparato a partir da Constituição Mexicana de1917 e da Constituição de Weimar de 1919 ocorreu a plena afirmação de direitos humanos de caráter econômico e social. ${ }^{45}$

Nota-se que os direitos sociais aqui mencionados reportam à pessoa individual, sendo distintos dos direitos coletivos/ difusos, que integram uma terceira dimensão de direitos. ${ }^{46} \mathrm{O}$ termo "sociais" nesse contexto refere-se à ideia de que esses direitos envolvem um aprofundamento da justiça social na medida em que correspondem a algumas das reivindicações das classes menos favorecidas, em especial do proletariado, e visam assegurar um mínimo existencial. ${ }^{47}$

\footnotetext{
${ }^{43}$ SARLET, Ingo Wolfang. A eficácia dos direitos fundamentais: uma teoria geral dos direitos

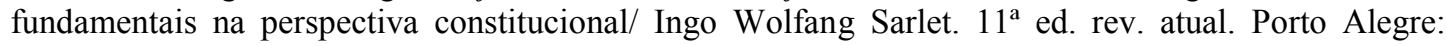
Livraria do Advogado Editora, 2012. p. 32.

${ }^{44}$ SARLET, Ingo Wolfang. A eficácia dos direitos fundamentais: uma teoria geral dos direitos fundamentais na perspectiva constitucional/ Ingo Wolfang Sarlet. $11^{\mathrm{a}}$ ed. rev. atual. Porto Alegre: Livraria do Advogado Editora, 2012. p. 32

${ }^{45}$ COMPARATO, Fábio Konder. A afirmação histórica dos direitos humanos/ Fábio Konder Comparato.- $4^{a}$ ed. rev. e atual.-São Paulo: Saraiva, 2005, p.53.

${ }^{46}$ SARLET, Ingo Wolfang. A eficácia dos direitos fundamentais: uma teoria geral dos direitos fundamentais na perspectiva constitucional/ Ingo Wolfang Sarlet. $11^{\mathrm{a}} \mathrm{ed}$. rev. atual. Porto Alegre: Livraria do Advogado Editora, 2012. p. 33.

${ }^{47}$ SARLET, Ingo Wolfang. A eficácia dos direitos fundamentais: uma teoria geral dos direitos fundamentais na perspectiva constitucional/ Ingo Wolfang Sarlet. 11 a ed. rev. atual. Porto Alegre: Livraria do Advogado Editora, 2012. p. 33.
} 


\subsection{Posição dos direitos humanos no sistema normativo}

Os direitos humanos assim são classificados pois tratam-se de direitos inerentes à condição do homem. ${ }^{48}$ No entanto, coloca-se a seguinte questão: o que dá caráter de obrigatoriedade a esses direitos?

A fim de responder essa pergunta deve-se recorrer à distinção entre direitos humanos e direitos fundamentais. ${ }^{49}$ Apesar de comumente utilizados como sinônimos o termo "direitos fundamentais" está relacionado aos direitos do ser humano que são definidos na esfera do direito constitucional positivo de um Estado. ${ }^{50} \mathrm{O}$ termo "direitos humanos", por sua vez, refere-se aos documentos de direito internacional, que reconhecem o ser humano como tal independente de vinculação a determinada ordem constitucional. ${ }^{51}$ Exatamente por isso, os direitos humanos têm validade universal, para todos os povos e tempos, eles possuem caráter internacional. ${ }^{52}$

Note-se que, apesar da diferença entre os considerados "direitos humanos" e os ditos "direitos fundamentais", não se deve deixar de lado a relação existente entre eles, pois a maior parte das Constituições do segundo pós-guerra tem inspiração na Declaração Universal de 1948, assim como nos documentos internacionais $\mathrm{e}$ regionais que a sucederam. ${ }^{53}$ Esse reconhecimento de direitos humanos por meio de diplomas legais confere

\footnotetext{
${ }^{48}$ COMPARATO, Fábio Konder. A afirmação histórica dos direitos humanos/ Fábio Konder Comparato.- $4^{\mathrm{a}}$ ed. rev. e atual.-São Paulo: Saraiva, 2005, p.57.

${ }^{49}$ COMPARATO, Fábio Konder. A afirmação histórica dos direitos humanos/ Fábio Konder Comparato.-4a ed. rev. e atual.-São Paulo: Saraiva, 2005, p.57.

${ }^{50}$ SARLET, Ingo Wolfang. A eficácia dos direitos fundamentais: uma teoria geral dos direitos fundamentais na perspectiva constitucional/ Ingo Wolfang Sarlet. $11^{\mathrm{a}}$ ed. rev. atual. Porto Alegre: Livraria do Advogado Editora, 2012. p. 19-21.

${ }^{51}$ SARLET, Ingo Wolfang. A eficácia dos direitos fundamentais: uma teoria geral dos direitos fundamentais na perspectiva constitucional/ Ingo Wolfang Sarlet. 11 a ed. rev. atual. Porto Alegre: Livraria do Advogado Editora, 2012. p. 19-21.

${ }^{52}$ SARLET, Ingo Wolfang. A eficácia dos direitos fundamentais: uma teoria geral dos direitos fundamentais na perspectiva constitucional/ Ingo Wolfang Sarlet. $11^{\mathrm{a}}$ ed. rev. atual. Porto Alegre: Livraria do Advogado Editora, 2012. p. 19-21.

${ }^{53}$ SARLET, Ingo Wolfang. A eficácia dos direitos fundamentais: uma teoria geral dos direitos fundamentais na perspectiva constitucional/ Ingo Wolfang Sarlet. 11 a ed. rev. atual. Porto Alegre: Livraria do Advogado Editora, 2012. p. 20.
} 
segurança às relações sociais.

É importante ressaltar que a eficácia jurídica e social dos direitos humanos que não integram o rol dos direitos fundamentais de um Estado depende da sua recepção na ordem jurídica interna e do status jurídico que ela lhes atribui. ${ }^{54}$ Logo, torna-se evidente que a efetivação dos direitos humanos depende da cooperação dos Estados. ${ }^{55}$

No entanto, a positivação de direitos humanos nas Constituições não impede que "falsos direitos humanos", impostos por uma minoria dominante que quer proteger seus privilégios, também sejam inseridos nesses diplomas normativos. ${ }^{56}$ Assim, torna-se evidente que é necessário fundamento mais profundo do que o mero reconhecimento internacional para a classificação de um direito como humano. ${ }^{57}$

Assim, ensina Konder que apenas "[...]a consciência ética coletiva, a conviç̧ão longa e largamente estabelecida na comunidade, de que a dignidade da condição humana exige o respeito a certos bens ou valores em qualquer circunstância [...]" ${ }^{58}$ pode servir de fundamento para a classificação do que são direitos humanos. Essa premissa, por si só, já rebate a objeção positivista de que direitos humanos não reconhecidos no ordenamento estatal não podem ter a sua observância exigida em juízo. ${ }^{59}$ Ora, defender a objeção positivista seria o mesmo que não reconhecer a eficácia de costumes e princípios gerais de

\footnotetext{
${ }^{54}$ SARLET, Ingo Wolfang. A eficácia dos direitos fundamentais: uma teoria geral dos direitos fundamentais na perspectiva constitucional/ Ingo Wolfang Sarlet. $11^{\mathrm{a}}$ ed. rev. atual. Porto Alegre: Livraria do Advogado Editora, 2012. p. 21.

${ }^{55}$ SARLET, Ingo Wolfang. A eficácia dos direitos fundamentais: uma teoria geral dos direitos fundamentais na perspectiva constitucional/ Ingo Wolfang Sarlet. $11^{\mathrm{a}}$ ed. rev. atual. Porto Alegre: Livraria do Advogado Editora, 2012. p. 21.

${ }^{56}$ COMPARATO, Fábio Konder. A afirmação histórica dos direitos humanos/ Fábio Konder Comparato.- $4^{\mathrm{a}}$ ed. rev. e atual.-São Paulo: Saraiva, 2005, p.58.

${ }^{57}$ COMPARATO, Fábio Konder. A afirmação histórica dos direitos humanos/ Fábio Konder Comparato.-4a ed. rev. e atual.-São Paulo: Saraiva, 2005, p.58.

${ }^{58}$ COMPARATO, Fábio Konder. A afirmação histórica dos direitos humanos/ Fábio Konder Comparato.-4a ed. rev. e atual.-São Paulo: Saraiva, 2005, p.59.

${ }^{59}$ COMPARATO, Fábio Konder. A afirmação histórica dos direitos humanos/ Fábio Konder Comparato.- $4^{\mathrm{a}}$ ed. rev. e atual.-São Paulo: Saraiva, 2005, p.59.
} 
direito. $^{60}$

Diante disso, é necessário esclarecer, no que tange a hierarquia normativa entre os direitos fundamentais, que as normas internacionais de direitos humanos prevalecem em relação ao ordenamento jurídico dos estados vez que refletem de certa forma a consciência ética universal. ${ }^{61}$ Logo, em caso de conflito entre as regras internacionais e internas que versam sobre direitos humanos, deve prevalecer a regra mais favorável à proteção da dignidade humana no caso concreto ${ }^{62}$.

Nesse contexto, pode-se observar que a ordem jurídica forma um "sistema dinâmico, isto é, um conjunto solidário de elementos criados para determinada finalidade e adaptável às mutações do meio onde atua" ${ }^{\text {63 }}$ sendo os direitos humanos um subsistema dela. A ordem jurídica é, assim, regida por princípios que buscam manter a sua coesão, permitindo o seu direcionamento diante das mudanças externas. ${ }^{64}$ Esses princípios são classificados como axiológicos quando remontam a tríade liberdade, igualdade, fraternidade (ou solidariedade). ${ }^{65}$

Vamos nos deter aqui ao exame do princípio da solidariedade, que nasceu com a intenção de superar o individualismo característico da civilização burguesa, fundada na liberdade e na isonomia. ${ }^{66}$ Esse princípio está relacionado à ideia de que todos são responsáveis pelas carências ou necessidades dos indivíduos. Ele se funda na justiça distributiva, compreendida

\footnotetext{
${ }^{60}$ COMPARATO, Fábio Konder. A afirmação histórica dos direitos humanos/ Fábio Konder Comparato.-4 $4^{\mathrm{a}}$ ed. rev. e atual.-São Paulo: Saraiva, 2005, p.60.

${ }^{61}$ COMPARATO, Fábio Konder. A afirmação histórica dos direitos humanos/ Fábio Konder Comparato.-4a ed. rev. e atual.-São Paulo: Saraiva, 2005, p.61.

${ }^{62}$ COMPARATO, Fábio Konder. A afirmação histórica dos direitos humanos/ Fábio Konder Comparato.-4 $4^{\mathrm{a}}$ ed. rev. e atual.-São Paulo: Saraiva, 2005, p.61.

${ }^{63}$ COMPARATO, Fábio Konder. A afirmação histórica dos direitos humanos/ Fábio Konder Comparato.- $4^{\mathrm{a}}$ ed. rev. e atual.-São Paulo: Saraiva, 2005, p.62.

${ }^{64}$ COMPARATO, Fábio Konder. A afirmação histórica dos direitos humanos/ Fábio Konder Comparato.-4a ed. rev. e atual.-São Paulo: Saraiva, 2005, p.62.

${ }^{65}$ COMPARATO, Fábio Konder. A afirmação histórica dos direitos humanos/ Fábio Konder Comparato.- $4^{\mathrm{a}}$ ed. rev. e atual.-São Paulo: Saraiva, 2005, p.62.

${ }^{66}$ COMPARATO, Fábio Konder. A afirmação histórica dos direitos humanos/ Fábio Konder Comparato. $-4^{\mathrm{a}}$ ed. rev. e atual.-São Paulo: Saraiva, 2005, p.64.
} 
como compensação de bens e vantagens entre as classes sociais com o fito de socializar os riscos da existência humana. ${ }^{67}$ Dessa forma, o princípio da solidariedade possibilitou o reconhecimento dos direitos sociais como direitos humanos. ${ }^{68}$

Os direitos sociais se realizam pela execução de políticas públicas que visam a proteção e o amparo dos menos favorecidos economicamente, estão relacionados ao asseguramento de um mínimo existencial. Encontram-se dentro da categoria de direitos sociais: o direito ao trabalho e seus consectários, $\mathrm{o}$ direito à seguridade social (que abarca o direito à saúde, previdência e assistência social), o direito à educação, dentre outros.

\footnotetext{
${ }^{67}$ COMPARATO, Fábio Konder. A afirmação histórica dos direitos humanos/ Fábio Konder Comparato.-4 ${ }^{\mathrm{a}}$ ed. rev. e atual.-São Paulo: Saraiva, 2005, p.64.

${ }^{68}$ COMPARATO, Fábio Konder. A afirmação histórica dos direitos humanos/ Fábio Konder Comparato.-4a ed. rev. e atual.-São Paulo: Saraiva, 2005, p.67.
} 


\section{Capítulo II- A positivação do Direito à Saúde}

No plano do direito internacional a Declaração Universal da ONU, de 1948, foi pioneira ao prever expressamente o direito à saúde em seus artigos 22 e 25. De acordo com ela, a segurança social e um padrão de vida capaz de assegurar a saúde e o bem-estar da pessoa humana são direitos humanos fundamentais. ${ }^{69}$

Em 1966, o Pacto Internacional dos Direitos Econômicos, Sociais e Culturais, ratificado pelo Brasil, em seu artigo 12 dispôs sobre o direito de desfrutar do mais alto grau de saúde física e mental. ${ }^{70}$

Posteriormente, em 1989, a Convenção sobre os Direitos da Criança e a Convenção Americana dos Direitos Humanos, ambas ratificadas pelo Brasil e incorporadas ao ordenamento jurídico interno fazem referência ao direito à saúde. ${ }^{71}$

Já no plano do Direito Constitucional Comparado, existem diversas constituições com previsão expressa do direito à saúde como direito fundamental. É o caso, por exemplo, das Constituições de Portugal, Holanda, Espanha, França, Itália, México, Argentina, Paraguai e Uruguai. ${ }^{72}$

\footnotetext{
${ }^{69}$ SARLET, Ingo Wolfang. Algumas considerações em torno do conteúdo, eficácia e efetividade do direito à saúde na constituição de 1988. Revista Eletrônica sobre a Reforma do Estado (RERE), Salvador, Instituto Brasileiro de Direito Público, $\mathrm{n}^{\circ}$ 11, setembro/outubro/novembro, 2007, p. 03. Disponível em: $<\underline{\text { http:}: / w w w . d i r e i t o d o e s t a d o . c o m . b r / r e r e . a s p . ~}>$. Acesso em: 01.04.2019.

${ }^{70}$ Pacto Internacional dos Direito Econômicos, Sociais e Culturais, promulgado pelo Brasil por meio do Decreto ${ }^{\circ} 591$ de 06.07.1992.

${ }^{71}$ SARLET, Ingo Wolfang. Algumas considerações em torno do conteúdo, eficácia e efetividade do direito à saúde na constituição de 1988. Revista Eletrônica sobre a Reforma do Estado (RERE), Salvador, Instituto Brasileiro de Direito Público, $\mathrm{n}^{\circ}$ 11, setembro/outubro/novembro, 2007, p. 04.

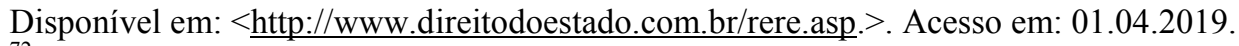

${ }^{72}$ SARLET, Ingo Wolfang. Algumas considerações em torno do conteúdo, eficácia e efetividade do direito à saúde na constituição de 1988. Revista Eletrônica sobre a Reforma do Estado (RERE), Salvador, Instituto Brasileiro de Direito Público, $\mathrm{n}^{\circ}$ 11, setembro/outubro/novembro, 2007, p. 04.

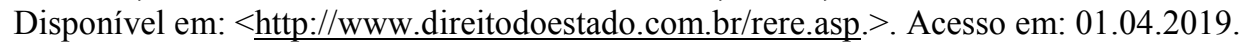




\subsection{O Direito à Saúde na Constituição Federal de 1988}

O direito à saúde apresenta-se pela primeira vez na Constituição da República dos Estados Unidos do Brasil, promulgada em 16 de julho de 1934. De acordo com o art. 10, II, do referido diploma legal, seria competência concorrente da União e dos Estados cuidar da saúde e assistência pública. Ainda, incumbiria à União, aos Estados e aos Municípios, nos termos do art. $138, f$ e $g$ : adotar medidas legislativas a fim de restringir a mortalidade e a morbidade infantis, de higiene social que impedissem a propagação de doenças transmissíveis, cuidar da higiene mental e incentivar a luta contra os venenos sociais. Note-se que essa Constituição, em seu art. 121, $\underline{h}$, incluiu como preceito no capítulo da ordem econômica e social a necessidade de observância pela legislação trabalhista da assistência médica e sanitária. ${ }^{73}$

As constituições brasileiras subsequentes à de 1934 e anteriores à de 1988 não trouxeram avanço significativo no que tange o direito à saúde, se limitando a atribuir à União a competência para planejar sistemas nacionais de saúde a ela garantindo competência exclusiva para estabelecer normas gerais de proteção e defesa da saúde. ${ }^{74}$

Significativas mudanças ocorreram na positivação do direito à saúde após a redemocratização. A força dos movimentos populares, em especial do "movimento sanitarista", permitiu que o direito à saúde fosse introduzido no rol dos direitos sociais na Constituição Federal de 1988 e fosse criado o Sistema Único de Saúde ${ }^{75}$.

\footnotetext{
${ }^{73}$ DALLARI, Sueli Gandolfi. A Construção do Direito à Saúde no Brasil. Revista de Direito Sanitário, São Paulo, v. 9, n. 3, p. 9-34, Nov. 2008/ Fev. 2009, pp 10. Disponível em: $<$ http://www.revistas.usp.br/rdisan/article/view/13128/14932>. Acesso em: 13.03.2019.

${ }^{74}$ DALLARI, Sueli Gandolfi. A Construção do Direito à Saúde no Brasil. Revista de Direito Sanitário, São Paulo, v. 9, n. 3, p. 9-34, Nov. 2008/ Fev. 2009, pp 10. Disponível em: $<$ http://www.revistas.usp.br/rdisan/article/view/13128/14932>. Acesso em: 13.03.2019.

${ }^{75}$ BARROSO, Luís Roberto. Da falta de efetividade à judicialização excessiva: direito à saúde, fornecimento gratuito de medicamentos e parâmetros para a atuação judicial. Jurisp. Mineira, Belo Horizonte, a. $60, \mathrm{n}^{\mathrm{o}} 188, \quad$ p. 29-60, jan./mar. 2009, p. 40. Disponível em:

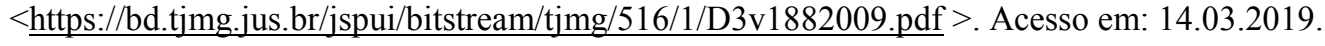


A Constituição Federal de 1988, em consonância com o disposto na carta de 1934, em seu art. 24, XII, e 30, I c/c VII e II, atribuiu competência concorrente à União, Estados e ao Distrito Federal para legislarem sobre a proteção e a defesa da saúde. ${ }^{76}$ Assim, ficou estabelecido que cabe à União elaborar normas gerais nos termos do art. 24, parágrafo $1^{\circ}$. Os Estados, por sua vez, de acordo com o art. 24, parágrafo $2^{\circ}$, devem suplementar a legislação federal. Aos Municípios, no art. 30, I e II, é atribuída a competência para legislar sobre assuntos de interesse local de forma a suplementar a legislação federal e a estadual. ${ }^{77}$

A Carta Maior, ainda, garantiu aos entes federativos competência comum para a formulação e execução de políticas de saúde no art. 23, II. ${ }^{78}$

Alinhada com a evolução constitucional contemporânea e com o direito internacional, a Constituição Federal de 1988 consagrou o direito à saúde como direito de todos e dever do Estado, garantido mediante políticas sociais e econômicas que visem à redução do risco de doença e de outros agravos e ao acesso universal e igualitário às ações e serviços para a sua promoção, proteção e recuperação nos termos do art. $196 .{ }^{79}$ Assim, o direito à saúde, como bem jurídico digno de tutela constitucional, pôde alçar a categoria de direito fundamental, recebendo proteção jurídica especial. ${ }^{80}$

\footnotetext{
${ }^{76}$ BARROSO, Luís Roberto. Da falta de efetividade à judicialização excessiva: direito à saúde, fornecimento gratuito de medicamentos e parâmetros para a atuação judicial. Jurisp. Mineira, Belo Horizonte, a. $60, \quad \mathrm{n}^{\mathrm{o}} 188, \quad$ p. 29-60, jan./mar. 2009, p. 40. Disponível em: $<$ https://bd.tjmg.jus.br/jspui/bitstream/tjmg/516/1/D3v1882009.pdf $>$. Acesso em: 14.03.2019.

${ }^{77}$ BARROSO, Luís Roberto. Da falta de efetividade à judicialização excessiva: direito à saúde, fornecimento gratuito de medicamentos e parâmetros para a atuação judicial. Jurisp. Mineira, Belo Horizonte, a. $60, \mathrm{n}^{\mathrm{o}} 188, \quad$ p. 29-60, jan./mar. 2009, p. 40. Disponível em: $<$ https://bd.tjmg.jus.br/jspui/bitstream/tjmg/516/1/D3v1882009.pdf $>$. Acesso em: 14.03.2019.

${ }^{78}$ BARROSO, Luís Roberto. Da falta de efetividade à judicialização excessiva: direito à saúde, fornecimento gratuito de medicamentos e parâmetros para a atuação judicial. Jurisp. Mineira, Belo Horizonte, a. $60, \mathrm{n}^{\mathrm{o}} 188, \quad$ p. 29-60, jan./mar. 2009, p. 40. Disponível em: $<$ https://bd.tjmg.jus.br/jspui/bitstream/tjmg/516/1/D3v1882009.pdf > . Acesso em: 14.03.2019.

${ }^{79}$ SILVA, José Afonso da. Curso de direito constitucional positivo-38 $8^{\mathrm{a}}$ ed. revista e atualizada.-São Paulo: Malheiros Editores Ltda., 2014, p. 312

${ }^{80}$ SARLET, Ingo Wolfang. Algumas considerações em torno do conteúdo, eficácia e efetividade do direito à saúde na constituição de 1988. Revista Eletrônica sobre a Reforma do Estado (RERE), Salvador, Instituto Brasileiro de Direito Público, $\mathrm{n}^{\circ}$ 11, setembro/outubro/novembro, 2007, p. 02. Disponível em: $<\underline{\text { http://www.direitodoestado.com.br/rere.asp. }}$. . Acesso em: 01.04.2019.
} 
De acordo com Ingo Sarlet, a proteção jurídica especial conferida ao direito baseia-se na dupla fundamentalidade a ele atribuída: a formal e a material. ${ }^{81}$

A fundamentalidade formal está relacionada ao fato de o direito à saúde ser integrante da Constituição escrita, diploma normativo que se encontra no ápice do ordenamento jurídico, norma de hierarquia superior. Por ser norma fundamental inserida na Constituição escrita submete-se aos limites formais (“procedimento agravado para modificação de preceitos constitucionais",82) e materiais (as cláusulas pétreas). Além disso, conforme preceitua o art. $5^{\circ}$, parágrafo $1^{\circ}$, da Constituição, as normas definidoras de direito e garantias fundamentais são diretamente aplicáveis, vinculando diretamente as entidades estatais e particulares. ${ }^{83}$

Já a fundamentalidade material está relacionada à relevância do bem jurídico tutelado na ordem constitucional. Notoriamente a saúde tem uma importância ímpar para a vida com dignidade. ${ }^{84}$

\footnotetext{
${ }^{81}$ SARLET, Ingo Wolfang. Algumas considerações em torno do conteúdo, eficácia e efetividade do direito à saúde na constituição de 1988. Revista Eletrônica sobre a Reforma do Estado (RERE), Salvador, Instituto Brasileiro de Direito Público, $\mathrm{n}^{\circ}$ 11, setembro/outubro/novembro, 2007, p. 03. Disponível em: $<\underline{\text { http:}: / w w w . d i r e i t o d o e s t a d o . c o m . b r / r e r e . a s p . ~}>$. Acesso em: 01.04.2019.

${ }^{82}$ SARLET, Ingo Wolfang. Algumas considerações em torno do conteúdo, eficácia e efetividade do direito à saúde na constituição de 1988. Revista Eletrônica sobre a Reforma do Estado (RERE), Salvador, Instituto Brasileiro de Direito Público, $\mathrm{n}^{\circ}$ 11, setembro/outubro/novembro, 2007, p. 03. Disponível em: $<\underline{\text { http:}: / w w w . d i r e i t o d o e s t a d o . c o m . b r / r e r e . a s p . ~}>$. Acesso em: 01.04.2019.

${ }^{83}$ SARLET, Ingo Wolfang. Algumas considerações em torno do conteúdo, eficácia e efetividade do direito à saúde na constituição de 1988. Revista Eletrônica sobre a Reforma do Estado (RERE), Salvador, Instituto Brasileiro de Direito Público, $\mathrm{n}^{\circ}$ 11, setembro/outubro/novembro, 2007, p. 03. Disponível em: $<$ http://www.direitodoestado.com.br/rere.asp. $>$. Acesso em: 01.04.2019.

${ }^{84}$ SARLET, Ingo Wolfang. Algumas considerações em torno do conteúdo, eficácia e efetividade do direito à saúde na constituição de 1988. Revista Eletrônica sobre a Reforma do Estado (RERE), Salvador, Instituto Brasileiro de Direito Público, $\mathrm{n}^{\circ}$ 11, setembro/outubro/novembro, 2007, p. 03.

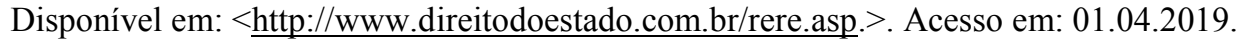




\subsection{O Direito à Saúde na legislação infraconstitucional: a Lei do SUS, o Estatuto do Idoso e o Estatuto da Criança e do Adolescente}

A Constituição Federal de 1988 ao dispor que a saúde é um direito de todos e um dever do estado ${ }^{85}$ reconheceu que seria necessário para efetivar a execução das ações e serviços públicos de saúde a organização de uma rede regionalizada e hierarquizada, de forma a constituir um sistema único. ${ }^{86}$

Com o intuito de dar efetividade à norma constitucional, em 1990 foi sancionada a Lei $\mathrm{n}^{\circ} 8.080$, também conhecida como Lei do Sistema Único de Saúde (Lei do SUS). Esse diploma legal visa dispor sobre as condições para a promoção, proteção e recuperação da saúde, organização e o funcionamento dos serviços correspondentes. ${ }^{87}$ Para tanto, em seu art. $1^{\circ}$, regula em todo o território nacional as ações e serviços de saúde, executados isolada ou conjuntamente, em caráter permanente ou eventual, por pessoas naturais ou jurídicas de direito público ou privado. ${ }^{88}$

A fim de tornar viável a atuação das pessoas naturais ou jurídicas de direito público ou privado na seara da saúde, a lei define o direito à saúde como um direito fundamental ${ }^{89}$. Nesse sentido, impõe ao Estado prestação positiva no que tange a criação das condições indispensáveis para o exercício desse direito. ${ }^{90}$ De forma ainda mais detalhada, a lei especifica quais os deveres do estado a fim de garantir o direito à saúde. Assim, determina que cabe ao Estado a formulação e execução de políticas econômicas e sociais que visem a redução de riscos de doenças e de outros agravos, o estabelecimento de condições que assegurem o acesso universal e igualitário às ações e serviços para a sua proteção e recuperação ${ }^{91}$ e ações que visam garantir às pessoas e à

\footnotetext{
${ }^{85}$ Artigo 196 da Constituição da República Federativa do Brasil de 1988.

${ }^{86}$ Artigo 198 da Constituição da República Federativa do Brasil de 1988.

${ }^{87}$ Ementa da Lei 8.080 de 19 de setembro de 1990 (Lei do SUS).

${ }^{88}$ Artigo $1^{\circ}$ da Lei 8.080 de 19 de setembro de 1990 (Lei do SUS).

${ }^{89}$ Artigo $2^{\circ}$, caput da Lei 8.080 de 19 de setembro de 1990 (Lei do SUS).

${ }^{90}$ Artigo $2^{\circ}$, caput da Lei 8.080 de 19 de setembro de 1990 (Lei do SUS).

${ }^{91}$ Artigo $2^{\circ}$, parágrafo $1^{\circ}$ da Lei 8.080 de 19 de setembro de 1990 (Lei do SUS).
} 
coletividade condições de bem estar físico, mental e social. ${ }^{92}$

Note-se que diante da relevância do direito à saúde a lei expressamente dispõe que os deveres do Estado não excluem o das pessoas, família, empresas e sociedade. ${ }^{93}$ Assim, se pode vislumbrar não só a eficácia vertical e horizontal do direito à saúde mas também a eficácia diagonal desse direito.

De acordo com Sérgio Gamon Contreras, ${ }^{94}$ a eficácia diagonal dos direitos fundamentais é presente quando as relações privadas (particularparticular) são marcadas por uma manifesta desigualdade de forças em razão da vulnerabilidade ou hipossuficiência de uma das partes. Ora, quando se considera que além do Estado pessoas, famílias, empresas e a sociedade, nos termos do art. $2^{\circ}$, parágrafo $2^{\circ}$, da Lei do Sistema Único de Saúde (Lei do SUS), têm o dever de tutelarem o direito à saúde, não se pode esquecer que quem clama por esse direito encontra-se em situação vulnerável, necessitando de cuidados e auxílio médico para a preservação de sua vida.

O Estatuto do Idoso (Lei $\mathrm{n}^{\mathrm{o}}$ 10.741/2003), assim como a Lei do SUS, classifica o direito à saúde como um direito fundamental e assegura todas as oportunidades e facilidades para a preservação da saúde em sua dimensão física e mental. ${ }^{95}$ Também em consonância com o previsto na Lei do SUS o Estatuto do Idoso determina que é obrigação da família, da comunidade, da sociedade e do poder público assegurar ao idoso a efetivação do direito à saúde. ${ }^{96}$ Assim, mais uma vez temos reforçada a ideia de que esse direito fundamental possui eficácia vertical, horizontal e diagonal.

De acordo com Fabiana Rodrigues Barletta ${ }^{97}$ a saúde é um direito

\footnotetext{
${ }^{92}$ Artigo $3^{\circ}$, parágrafo único da Lei 8.080 de 19 de setembro de 1990 (Lei do SUS).

${ }^{93}$ Artigo $2^{\circ}$, parágrafo $2^{\circ}$ da Lei 8.080 de 19 de setembro de 1990 (Lei do SUS).

${ }^{94}$ Sérgio Gamon Contreras apud VAILLATTI, Diogo Basílio. Resenha Cidadania da Empresa e Eficácia Diagonal dos Direitos Fundamentais. (RE)PENSANDO DIREITO. CNECEdigraf. Ano 5. $\mathrm{n}$. 10. jul./dez. p. 237-240. 2015. p. 240. Disponível em: $<$ http://local.cnecsan.edu.br/revista/index.php/direito/article/view/263/190 $>$. Acesso em 01.04.2019.

${ }^{95}$ Artigo $2^{\circ}$ da Lei $n^{\circ} 10.741$ de 01 de outubro de 2003 (Estatuto do Idoso).

${ }^{96}$ Artigo $2^{\circ}$ da Lei ${ }^{\circ} 10.741$ de 01 de outubro de 2003 (Estatuto do Idoso).

${ }^{97}$ BARLETTA, Fabiana Rodrigues. A pessoa idosa e seu direito prioritário à saúde: Apontamentos a partir do princípio do melhor interesse do idoso. Revista de Direito Sanitário, São Paulo, v. 15, n.1, p.
} 
prioritário da pessoa idosa pois em conjunto com os direitos componentes da seguridade social no Brasil "ela é pré-requisito para que os idosos tenham acesso ao trabalho, à educação, à cultura, ao lazer, ao exercício de direitos civis e políticos, em condições de liberdade e dignidade".

Nesse sentido, o Estatuto do Idoso dedica capítulo especial para tratar do direito à saúde. Destaca-se a garantia de atenção integral à saúde do idoso, o que seria viabilizado pelo Sistema Único de Saúde que atuaria em conjunto com ações e serviços para a prevenção, promoção, proteção e recuperação da saúde. ${ }^{98} \mathrm{O}$ art. 15 , parágrafo $1^{\circ}$, com o fito de dar mais concretude às ações de prevenção e manutenção à saúde do idoso, as exemplifica. Assim, infere-se que é possível prevenir e manter a saúde dos idosos por meio do cadastramento da pessoa idosa em base territorial, do atendimento geriátrico e gerontológico em ambulatórios, unidades geriátricas de referência com pessoal especializado, atendimento domiciliar incluindo internação para a população que necessitar e reabilitação orientada pela geriatria e gerontologia para a redução de sequelas em decorrência de problemas de saúde. ${ }^{99}$

O Estatuto da Criança e do Adolescente (Lei no 8.069/90), por sua vez, tutela o direito fundamental à saúde da criança e do adolescente partindo da premissa de que esse direito goza de certa especialidade em relação ao direito fundamental à saúde dos adultos. Nesse sentido, Martha de T. Machado, explica:

“[...] as especificidades dos direitos fundamentais das crianças e adolescentes no plano do direito material, estão fundadas na peculiar condição de pessoa em desenvolvimento (e com as particulares características que busquei desenvolver no Capítulo 5), e na medida em que tais especificidades distinguem completamente os direitos fundamentais de crianças e adolescentes dos direitos fundamentais dos

\footnotetext{
119-136, mar./jun. $2014, \quad$ p. $127 . \quad$ Disponível em: $<$ http://www.revistas.usp.br/rdisan/article/view/82809>. Acesso em: 20.03.2019.

${ }^{98}$ Artigo 15 da Lei $\mathrm{n}^{\circ} 10.741$ de 01 de outubro de 2003 (Estatuto do Idoso).

${ }^{99}$ Artigo 15, parágrafo $1^{\circ}$, incisos I a V da Lei ${ }^{\circ} 10.741$ de 01 de outubro de 2003 (Estatuto do Idoso).
} 
adultos, com maior razão me parece que são elas que determinam as particularidade da tutela jurisdicional desses direitos". ${ }^{100}$

Assim, sob a perspectiva de que a criança e o adolescente são pessoas em desenvolvimento o art. $7^{\circ}$ do Estatuto da Criança e do Adolescente garante a eles proteção à vida e à saúde, o que seria viabilizado mediante a efetivação de políticas sociais e públicas que garantem o desenvolvimento sadio e harmonioso, em condições dignas de existência. ${ }^{101}$ É atribuído à família, à comunidade, à sociedade e ao poder público o dever de efetivar o direito fundamental à saúde. ${ }^{102}$

No âmbito do poder público é estabelecido que o Sistema Único de Saúde deve promover programas de assistência médica e odontológica com o fito de prevenir o acometimento de crianças e adolescentes por enfermidades que costumam afetar a população infantil, sem prejuízo da realização de campanhas de educação sanitária, inclusive para pais e educadores. ${ }^{103}$ Ainda, é atribuída ao Sistema Único de Saúde a realização de programas e políticas de saúde da mulher, planejamento reprodutivo e atendimento à gestante. ${ }^{104}$

Observa-se que o desenvolvimento sadio e harmonioso das crianças e adolescentes, pessoas em desenvolvimento, é tão relevante que o legislador se dedicou a abordar de forma específica a conduta a ser adotada por aqueles que possuem suspeita ou confirmação da submissão de criança ou adolescente a castigo físico, maus-tratos, tratamento cruel ou degradante. ${ }^{105}$ Isso confirma, mais uma vez, a especificidade dos direitos fundamentais da crianças e adolescentes, em especial, do direito à saúde.

\footnotetext{
${ }^{100}$ MACHADO, Martha de Toledo. A Proteção Constitucional de Crianças e Adolescentes e os Direitos Humanos/ Martha de Toledo Machado.-Barueri, SP: Manole, 2003, p.398.

${ }^{101}$ Artigo $7^{\circ}$ da Lei ${ }^{\circ} 8.069$ de 13 de julho de 1990 (Estatuto da Criança e do Adolescente).

${ }^{102}$ Artigo $4^{\circ}$ da Lei $n^{\circ} 8.069$ de 13 de julho de 1990 (Estatuto da Criança e do Adolescente).

${ }^{103}$ Artigo 14 da Lei no 8.069 de 13 de julho de 1990 (Estatuto da Criança e do Adolescente).

${ }^{104}$ Artigo $8^{\circ}$ da Lei no 8.069 de 13 de julho de 1990 (Estatuto da Criança e do Adolescente).

${ }^{105}$ Artigo 13 da Lei no 8.069 de 13 de julho de 1990 (Estatuto da Criança e do Adolescente).
} 


\section{Capítulo III - A efetivação do direito à saúde mediante a intervenção do Poder Judiciário}

O direito à saúde após a sua positivação na Constituição de 1988 conquistou força normativa e efetividade. ${ }^{106}$ Isso significa que se passou a entender que as normas constitucionais que regulam esse direito "são aplicáveis direta e imediatamente na extensão máxima de sua densidade normativa". ${ }^{107}$

Nesse contexto, interpreta-se a norma constitucional como detentora de um comando. Ela tutela direitos subjetivos direta e imediatamente exigíveis do Poder Público ou do particular. ${ }^{108}$ Salienta Ana Paula de Barcellos que os poderes constituídos, independente do plano de governo ou orientação política do grupo que está no poder, têm o dever de colocar à disposição das pessoas as prestações de saúde que integram o mínimo existencial. ${ }^{109}$

Dessa forma, quando ocorrida violação à norma constitucional por uma ação ou omissão, o ordenamento jurídico fornece meios para a tutela do direito ou bem jurídico protegido. ${ }^{110}$ Assim, o Poder Judiciário passa a "ter papel

\footnotetext{
${ }^{106}$ BARROSO, Luís Roberto. Da falta de efetividade à judicialização excessiva: direito à saúde, fornecimento gratuito de medicamentos e parâmetros para a atuação judicial. Jurisp. Mineira, Belo Horizonte, a. $60, \quad \mathrm{n}^{\mathrm{o}} 188, \quad$ p. 29-60, jan./mar. 2009, p. 35. Disponível em: $<$ https://bd.tjmg.jus.br/jspui/bitstream/tjmg/516/1/D3v1882009.pdf $>$. Acesso em: 20.03.2019.

${ }^{107}$ BARROSO, Luís Roberto. Da falta de efetividade à judicialização excessiva: direito à saúde, fornecimento gratuito de medicamentos e parâmetros para a atuação judicial. Jurisp. Mineira, Belo Horizonte, a. $60, \mathrm{n}^{\mathrm{o}} 188, \quad$ p. 29-60, jan./mar. 2009, p. 36. Disponível em: $<$ https://bd.tjmg.jus.br/jspui/bitstream/tjmg/516/1/D3v1882009.pdf > . Acesso em: 20.03.2019.

${ }^{108}$ BARROSO, Luís Roberto. Da falta de efetividade à judicialização excessiva: direito à saúde, fornecimento gratuito de medicamentos e parâmetros para a atuação judicial. Jurisp. Mineira, Belo Horizonte, a. $60, \quad \mathrm{n}^{\mathrm{o}} 188, \quad$ p. 29-60, jan./mar. 2009, p. 36. Disponível em: $<$ https://bd.tjmg.jus.br/jspui/bitstream/tjmg/516/1/D3v1882009.pdf > . Acesso em: 20.03.2019.

${ }^{109}$ BARCELLOS, Ana Paula de. A eficácia jurídica dos princípios constitucionais: O princípio da dignidade da pessoa humana. $-3^{\text {a }}$ ed. Revista e atualizada. -Rio de Janeiro: Renovar, 2011, p. 320.

110 BARROSO, Luís Roberto. Da falta de efetividade à judicialização excessiva: direito à saúde, fornecimento gratuito de medicamentos e parâmetros para a atuação judicial. Jurisp. Mineira, Belo Horizonte, a. 60, $\mathrm{n}^{\mathrm{o}} 188, \quad$ p. 29-60, jan./mar. 2009, p. 36. Disponível em: $<$ https://bd.tjmg.jus.br/jspui/bitstream/tjmg/516/1/D3v1882009.pdf $>$. Acesso em: 20.03.2019.
} 
decisivo na concretização da Constituição". ${ }^{111}$ Esse papel é problemático quando analisamos sob a perspectiva de quem decide, o magistrado, e sob a perspectiva do Poder Público, a quem incumbe realizar as políticas de saúde.

Em relação aos magistrados é necessário levar em conta que sua formação é baseada em conhecimentos lógico-dedutivos do ordenamento jurídico, gerando dificuldade de "processar juridicamente o que está posto em forma de políticas"112 ${ }^{113}$

Soma-se a essa dificuldade a impossibilidade de o juiz em sua atuação desconsiderar as suas impressões psicológicas e sociais. Nesse sentido Ana Paula de Barcellos discorre de forma precisa:

"Um doente com rosto, identidade, presença física e história pessoal, solicitando ao Juízo uma prestação de saúde - não incluída no mínimo existencial e nem autorizada por lei, mas sem a qual ele pode vir a falecer - é percebido de forma inteiramente diversa da abstração etérea do orçamento e das necessidades do restante da população, que não são visíveis naquele momento e têm a sua percepção distorcida pela incredulidade do magistrado, ou ao menos pela fundada dúvida de que os recursos públicos estejam sendo efetivamente utilizados na promoção da saúde básica.

[...] é compreensivelmente difícil para o juiz deixar de ceder à tentação de dar uma solução jurídica localizada e individual a um problema cujo espaço de discussão é essencialmente político."114

Já em relação ao poder público, a atuação do Poder Judiciário como "concretizador da Constituição" é problemática na medida em que permite a criação de um círculo vicioso que exime a autoridade pública da obrigação de realizar as normas constitucionais sob a justificativa de que aguardará decisões

\footnotetext{
${ }^{111}$ BARROSO, Luís Roberto. Da falta de efetividade à judicialização excessiva: direito à saúde, fornecimento gratuito de medicamentos e parâmetros para a atuação judicial. Jurisp. Mineira, Belo Horizonte, a. $60, \mathrm{n}^{\mathrm{o}} 188, \quad$ p. 29-60, jan./mar. 2009, p. 36. Disponível em: $<$ https://bd.tjmg.jus.br/jspui/bitstream/tjmg/516/1/D3v1882009.pdf $>$. Acesso em: 20.03.2019.

${ }^{12}$ NEPOMUCENO, M.; BELLATO, R.; ARAÚJO, L.; MUFATO, L. F. O campo jurídico na garantia do direito à saúde. Revista de Direito Sanitário, v. 14, n. 2, p. 119-136, 28 out. 2013. p. 120. Disponível em: < https://www.revistas.usp.br/rdisan/article/view/64321 >. Acesso em: 20.03.2019.

${ }^{113}$ NEPOMUCENO, M.; BELLATO, R.; ARAÚJO, L.; MUFATO, L. F. O campo jurídico na garantia do direito à saúde. Revista de Direito Sanitário, v. 14, n. 2, p. 119-136, 28 out. 2013. p. 120. Disponível em: < https://www.revistas.usp.br/rdisan/article/view/64321 > Acesso em: 20.03.2019.

${ }^{114}$ BARCELLOS, Ana Paula de. A eficácia jurídica dos princípios constitucionais: O princípio da dignidade da pessoa humana. $-3^{\text {a }}$ ed. Revista e atualizada. -Rio de Janeiro: Renovar, 2011, p. 322.
} 
judiciais sobre o tema ou de que não possui recursos para custear tais ou aquelas políticas. ${ }^{115}$

Ainda, apresenta-se problemática a atuação do Poder Judiciário na seara do direito à saúde pois muitas vezes é imposto ao poder público o custeio de tratamentos sofisticados e caros em decisões que acabam se tornando precedentes aplicados reiteradamente. ${ }^{116}$

Diante disso, cabe examinar detidamente os aspectos que permeiam as decisões judiciais e as diretrizes para a atuação do poder público no âmbito do direito à saúde. Apenas assim será possível traçar de forma mais eficaz as alternativas à judicialização desse direito fundamental.

\subsection{Princípio do mínimo existencial versus princípio da reserva do possível}

Quando se trata de direitos fundamentais, em especial do direito à saúde, é necessário considerar a distinção entre regras e princípios. De acordo com Robert Alexy, tal diferenciação é essencial para que se possa entender o papel dos direitos fundamentais no ordenamento jurídico e para que se possa solucionar questões que envolvem a sua restrição ou colisão. ${ }^{117}$ Ela contribui não só para a dogmática dos direitos de liberdade e igualdade mas também tem implicação nos direitos à proteção, à organização, aos procedimentos e às prestações. $^{118}$

Nesse contexto, cabe esclarecer que tanto as regras quanto os princípios são

\footnotetext{
${ }^{115}$ BARCELLOS, Ana Paula de. A eficácia jurídica dos princípios constitucionais: O princípio da dignidade da pessoa humana. $-3^{3}$ ed. Revista e atualizada. -Rio de Janeiro: Renovar, 2011, p. 322.

${ }^{116}$ BARCELLOS, Ana Paula de. A eficácia jurídica dos princípios constitucionais: O princípio da dignidade da pessoa humana. $-3^{a}$ ed. Revista e atualizada. -Rio de Janeiro: Renovar, 2011, p. 323.

${ }^{117}$ ALEXY, Robert. Teoria dos Direitos Fundamentais. Tradução de Virgílio Afonso da Silva da $5^{\text {a }}$ edição alemã Theorie der Grundrechte publicada pela Suhrkamp Velarg (2006). São Paulo: Malheiros Editores, 2008, p.85.

${ }^{118}$ ALEXY, Robert. Teoria dos Direitos Fundamentais. Tradução de Virgílio Afonso da Silva da $5^{\text {a }}$ edição alemã Theorie der Grundrechte publicada pela Suhrkamp Velarg (2006). São Paulo: Malheiros Editores, 2008, p.85.
} 
considerados normas pois dizem o que deve ser. ${ }^{119}$ Eles podem ser expressos por meio de proibições ou permissões. ${ }^{120}$

Os princípios são mandados de otimização, ou seja, "são normas que ordenam que algo seja realizado na maior medida possível dentro das possibilidades jurídicas e fáticas existentes" ${ }^{" 121}$. Assim, a satisfação de um princípio pode se dar em grau variado a depender dos dados de realidade e dos princípios e regras colidentes. ${ }^{122}$

As regras, por sua vez, são normas que podem ser satisfeitas ou não, pois traduzem "determinações no âmbito daquilo que é fática e juridicamente possível" $"$. Logo, a regra deve ser estritamente seguida, deve se fazer o que ela exige, nem mais, nem menos. ${ }^{124}$

Frequentemente as normas de direito fundamental são caracterizadas como princípios. ${ }^{125}$ É o caso do direito fundamental e garantia ao mínimo existencial. Ele é compreendido como "todo o conjunto de prestações materiais indispensáveis para assegurar a cada pessoa uma vida condigna, no sentido de vida saudável" ${ }^{\prime 26}$.

\footnotetext{
${ }^{119}$ ALEXY, Robert. Teoria dos Direitos Fundamentais. Tradução de Virgílio Afonso da Silva da $5^{\mathrm{a}}$ edição alemã Theorie der Grundrechte publicada pela Suhrkamp Velarg (2006). São Paulo: Malheiros Editores, 2008, p.87.

${ }^{120}$ ALEXY, Robert. Teoria dos Direitos Fundamentais. Tradução de Virgílio Afonso da Silva da $5^{\text {a }}$ edição alemã Theorie der Grundrechte publicada pela Suhrkamp Velarg (2006). São Paulo: Malheiros Editores, 2008, p.87.

${ }^{121}$ ALEXY, Robert. Teoria dos Direitos Fundamentais. Tradução de Virgílio Afonso da Silva da $5^{\text {a }}$ edição alemã Theorie der Grundrechte publicada pela Suhrkamp Velarg (2006). São Paulo: Malheiros Editores, 2008, p. 90.

${ }^{122}$ ALEXY, Robert. Teoria dos Direitos Fundamentais. Tradução de Virgílio Afonso da Silva da $5^{\mathrm{a}}$ edição alemã Theorie der Grundrechte publicada pela Suhrkamp Velarg (2006). São Paulo: Malheiros Editores, 2008, p.90.

${ }^{123}$ ALEXY, Robert. Teoria dos Direitos Fundamentais. Tradução de Virgílio Afonso da Silva da $5^{\mathrm{a}}$ edição alemã Theorie der Grundrechte publicada pela Suhrkamp Velarg (2006). São Paulo: Malheiros Editores, 2008, p.91.

${ }^{124}$ ALEXY, Robert. Teoria dos Direitos Fundamentais. Tradução de Virgílio Afonso da Silva da $5^{\mathrm{a}}$ edição alemã Theorie der Grundrechte publicada pela Suhrkamp Velarg (2006). São Paulo: Malheiros Editores, 2008, p.91.

${ }^{125}$ ALEXY, Robert. Teoria dos Direitos Fundamentais. Tradução de Virgílio Afonso da Silva da $5^{\text {a }}$ edição alemã Theorie der Grundrechte publicada pela Suhrkamp Velarg (2006). São Paulo: Malheiros Editores, 2008, p.86.

${ }^{126}$ SARLET, I.; FIGUEIREDO, M. Reserva do possível, mínimo existencial e direito à saúde. Revista Brasileira de Direitos Fundamentais \& Justiça, v. 1, n. 1, p. 171-213, 25 mar. 2007. p. 184.

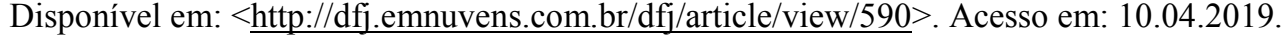


Apesar de não estar previsto expressamente na Constituição de 1988, no art. 170, caput, é consagrada a garantia à existência digna como um dos princípios e objetivos da ordem constitucional econômica. ${ }^{127}$ Além disso, os direitos sociais previstos na Constituição de 1988 abarcam algumas dimensões do direito fundamental ao mínimo existencial. ${ }^{128}$

É importante ressaltar que, conforme exposto por Ingo Sarlet e Mariana Figueiredo a previsão constitucional de direitos sociais "[...] não retira do mínimo existencial a sua condição de direito-garantia fundamental autônomo e muito menos não afasta a necessidade de se interpretar os demais direitos sociais à luz do próprio mínimo existencial [...]"129.

Assim, tendo em vista que o direito à saúde deve ser interpretado sob a ótica do princípio do mínimo existencial é possível concluir que existem prestações de saúde que são exigíveis do Poder Público em decorrência da Constituição ${ }^{130}$. Além desse conjunto de prestações mínimas, o Poder Público pode atender outras necessidades de saúde, o que é traduzido pelo art. 196, caput, da Constituição de 1988, que garante às pessoas acesso a todas as prestações necessárias para a promoção, proteção e recuperação de sua saúde. ${ }^{131}$

A diferença entre as prestações de saúde que compõem o mínimo existencial e as demais necessárias para a promoção, proteção e recuperação da saúde está relacionada ao tipo de tutela que o Poder Judiciário pode conferir a

\footnotetext{
${ }^{127}$ SARLET, I.; FIGUEIREDO, M. Reserva do possível, mínimo existencial e direito à saúde. Revista Brasileira de Direitos Fundamentais \& Justiça, v. 1, n. 1, p. 171-213, 25 mar. 2007. p. 184. Disponível em: $<$ http://dfj.emnuvens.com.br/dfj/article/view/590 $>$. Acesso em: 10.04.2019.

${ }^{128}$ SARLET, I.; FIGUEIREDO, M. Reserva do possível, mínimo existencial e direito à saúde. Revista Brasileira de Direitos Fundamentais \& Justiça, v. 1, n. 1, p. 171-213, 25 mar. 2007. p. 184. Disponível em: $<$ http://dfj.emnuvens.com.br/dfj/article/view/590>. Acesso em: 10.04.2019.

${ }^{129}$ SARLET, I.; FIGUEIREDO, M. Reserva do possível, mínimo existencial e direito à saúde. Revista Brasileira de Direitos Fundamentais \& Justiça, v. 1, n. 1, p. 171-213, 25 mar. 2007. p. 184. Disponível em: $<$ http://dfj.emnuvens.com.br/dfj/article/view/590>. Acesso em: 10.04.2019.

${ }^{130}$ BARCELLOS, Ana Paula de. A eficácia jurídica dos principios constitucionais: O princípio da dignidade da pessoa humana. $-3^{\text {a }}$ ed. Revista e atualizada. -Rio de Janeiro: Renovar, 2011, p. 320.

${ }^{131}$ BARCELLOS, Ana Paula de. A eficácia jurídica dos princípios constitucionais: O princípio da dignidade da pessoa humana. $-3^{\text {a }}$ ed. Revista e atualizada. -Rio de Janeiro: Renovar, 2011, p. 320.
} 
elas. ${ }^{132}$ Em relação às prestações de saúde que compõe o mínimo existencial, o Poder Judiciário pode e deve determinar o fornecimento da prestação de saúde baseando-se no disposto na Constituição Federal, "independentemente de existir uma ação específica da Administração ou do Legislativo nesse sentido" ${ }^{233}$. Isso, porquê, as normas constitucionais sobre dignidade humana e saúde possuem eficácia positiva ou simétrica, ou seja, não dependem da interveniência legislativa. ${ }^{134}$

Diante disso, coloca-se a seguinte questão: quais prestações de saúde compõem o mínimo existencial? De acordo com Ana Paula de Barcellos as prestações que compõem o mínimo existencial devem ser aquelas disponíveis e possivelmente indispensáveis para o restabelecimento ou manutenção da saúde do paciente, independentemente da sua condição, pois não se pode ter ingerência sobre o resultado que será produzido. ${ }^{135}$ Elas poderão ser exigidas judicialmente do Poder Público que, caso não as possa executar, deverá custeálas.

Conforme pode se observar, o direito à saúde, como direito de eficácia positiva, impõe prestações estatais vinculadas à sua promoção, proteção e recuperação. Isso significa que devem ser criadas condições materiais para a sua efetivação, o que transparece na sua dimensão economicamente relevante. Esclarecem Ingo Sarlet e Mariana Figueiredo:

"Já no que diz com os direitos sociais a prestações, seu "custo" assume especial relevância no âmbito de sua eficácia e efetivação, significando, pelo menos para grande parte da doutrina, que a efetiva realização das prestações reclamadas não é possível sem que se aloque algum recurso, dependendo em última análise, da conjuntura econômica, já que aqui está em causa a possibilidade de os órgãos

\footnotetext{
${ }^{132}$ BARCELLOS, Ana Paula de. A eficácia jurídica dos princípios constitucionais: O princípio da dignidade da pessoa humana. $-3^{a}$ ed. Revista e atualizada. -Rio de Janeiro: Renovar, 2011, p. 320-321. ${ }^{133}$ BARCELLOS, Ana Paula de. A eficácia jurídica dos princípios constitucionais: O princípio da dignidade da pessoa humana. $-3^{\mathrm{a}}$ ed. Revista e atualizada. -Rio de Janeiro: Renovar, 2011, p. 320.

${ }^{134}$ BARCELLOS, Ana Paula de. A eficácia jurídica dos princípios constitucionais: O princípio da dignidade da pessoa humana. $-3^{\text {a }}$ ed. Revista e atualizada. -Rio de Janeiro: Renovar, 2011, p. 321.

${ }^{135}$ BARCELLOS, Ana Paula de. A eficácia jurídica dos princípios constitucionais: O princípio da dignidade da pessoa humana. $-3^{a}$ ed. Revista e atualizada. -Rio de Janeiro: Renovar, 2011, p. 324-326
} 
jurisdicionais imporem ao poder público a satisfação das prestações reclamadas."136

Assim, torna-se evidente a problemática relacionada à condição do Poder Público realizar as prestações determinadas pela norma quando inexistem meios econômicos de cumprir a sua obrigação. ${ }^{137}$

Diante disso, foi construída na Alemanha nos anos de 1970 a teoria da reserva do possível. ${ }^{138}$ De acordo com ela, "a efetividade dos direitos sociais a prestações materiais estaria sob a reserva das capacidades financeiras do estado"139. Ou seja, os direitos sociais que implicariam em prestações a serem fornecidas teriam a sua efetivação condicionada à disponibilidade dos recursos financeiros do Estado, que teria discricionariedade para elaborar o seu orçamento. ${ }^{140}$ Dessa forma, a reserva do possível apresenta-se como um limite jurídico e fático à efetivação jurídica e política dos direitos fundamentais. ${ }^{141}$

Justamente por ser um limite fático e jurídico à efetivação de direitos fundamentais, a reserva do possível deve ser interpretada com reservas. Notoriamente o Estado possui limitações financeiras ao implemento das prestações necessárias para a garantia do direito à saúde. No entanto, não se pode invocar a reserva do possível como argumento que impeça a atuação judicial e nem como justificativa para a omissão estatal no que tange a

\footnotetext{
${ }^{136}$ SARLET, I.; FIGUEIREDO, M. Reserva do possível, mínimo existencial e direito à saúde. Revista Brasileira de Direitos Fundamentais \& Justiça, v. 1, n. 1, p. 171-213, 25 mar. 2007. p. 187. Disponível em: $<$ http://dfj.emnuvens.com.br/dfj/article/view/590 > . Acesso em: 10.04.2019.

${ }^{137}$ SARLET, I.; FIGUEIREDO, M. Reserva do possível, mínimo existencial e direito à saúde. Revista Brasileira de Direitos Fundamentais \& Justiça, v. 1, n. 1, p. 171-213, 25 mar. 2007. p. 187. Disponível em: $<$ http://dfj.emnuvens.com.br/dfj/article/view/590 > . Acesso em: 10.04.2019.

${ }^{138}$ SARLET, I.; FIGUEIREDO, M. Reserva do possível, mínimo existencial e direito à saúde. Revista Brasileira de Direitos Fundamentais \& Justiça, v. 1, n. 1, p. 171-213, 25 mar. 2007. p. 188. Disponível em: $<$ http://dfj.emnuvens.com.br/dfj/article/view/590 $>$. Acesso em: 10.04.2019.

${ }^{139}$ SARLET, I.; FIGUEIREDO, M. Reserva do possível, mínimo existencial e direito à saúde. Revista Brasileira de Direitos Fundamentais \& Justiça, v. 1, n. 1, p. 171-213, 25 mar. 2007. p. 188. Disponível em: $<$ http://dfj.emnuvens.com.br/dfj/article/view/590 > . Acesso em: 10.04.2019.

${ }^{140}$ SARLET, I.; FIGUEIREDO, M. Reserva do possível, mínimo existencial e direito à saúde. Revista Brasileira de Direitos Fundamentais \& Justiça, v. 1, n. 1, p. 171-213, 25 mar. 2007. p. 188. Disponível em: $<$ http://dfj.emnuvens.com.br/dfj/article/view/590 $>$. Acesso em: 10.04.2019.

${ }^{141}$ SARLET, I.; FIGUEIREDO, M. Reserva do possível, mínimo existencial e direito à saúde. Revista Brasileira de Direitos Fundamentais \& Justiça, v. 1, n. 1, p. 171-213, 25 mar. 2007. p. 191.

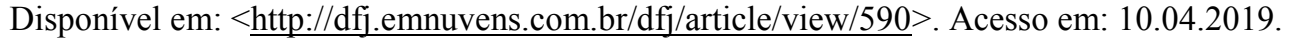


efetivação desse direito. ${ }^{142}$

Na realidade, o Poder Público, quando invoca a reserva do possível, tem o ônus de comprovar que não possui recursos para oferecer as prestações necessárias à efetivação do direito à saúde e de demonstrar que aplica os recursos visando a maximização da eficácia e efetividade desse direito fundamental. ${ }^{143}$

Nesse contexto, conclui-se que o princípio do mínimo existencial é instrumento para a alocação dos recursos públicos de forma eficaz e efetiva, pois serve como "parâmetro de reconhecimento de direitos subjetivos a prestações" ${ }^{\prime 144}$. Assim, os recursos disponíveis devem ser utilizados para o atendimento das prestações de saúde relacionadas com o mínimo existencial, tornando descabida a invocação da reserva do possível para eximir a atuação do Poder Público.

\subsection{Violação ao Princípio da Equidade?}

A alocação dos recursos públicos na seara do direito à saúde deve ser vista com cautela. Tendo em vista que esse direito é de eficácia positiva, ou seja, impõe prestações estatais para a sua promoção, proteção e recuperação, devem ser criadas condições materiais para a sua efetivação. No entanto, muitas vezes não há recursos suficientes para tanto.

A Constituição Federal de 1988 mitiga de certa forma essa questão pois nos artigos 195, parágrafo $2^{\circ}$, inciso II, e 198, parágrafo $2^{\circ}$, incisos I e III, estabelece recursos mínimos que devem ser destinados ao setor de saúde. De

\footnotetext{
${ }^{142}$ SARLET, I.; FIGUEIREDO, M. Reserva do possível, mínimo existencial e direito à saúde. Revista Brasileira de Direitos Fundamentais \& Justiça, v. 1, n. 1, p. 171-213, 25 mar. 2007. p. 191. Disponível em: $<$ http://dfj.emnuvens.com.br/dfj/article/view/590 $>$. Acesso em: 12.04.2019.

${ }^{143}$ SARLET, I.; FIGUEIREDO, M. Reserva do possível, mínimo existencial e direito à saúde. Revista Brasileira de Direitos Fundamentais \& Justiça, v. 1, n. 1, p. 171-213, 25 mar. 2007. p. 191-196. Disponível em: <http://dfj.emnuvens.com.br/dfj/article/view/590>. Acesso em: 12.04.2019.

${ }^{144}$ SARLET, I.; FIGUEIREDO, M. Reserva do possível, mínimo existencial e direito à saúde. Revista Brasileira de Direitos Fundamentais \& Justiça, v. 1, n. 1, p. 171-213, 25 mar. 2007. p. 191.

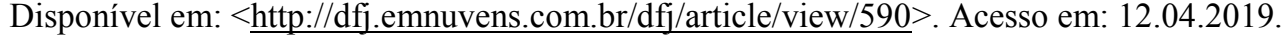


acordo com esses artigos, a União deve destinar o valor mínimo equivalente ao gasto do exercício anterior mais variação do PIB, os Estados 12\% da receita tributária anual, os Municípios $15 \%$ da receita tributária anual e o Distrito Federal $12 \%$ da receita correspondente à competência tributária estadual e 15\% da receita correspondente à competência tributária municipal.

Assim, resta analisar como devem ser alocados os recursos destinados ao custeio das políticas de promoção, proteção e recuperação da saúde.

Conforme já exposto neste trabalho, um parâmetro que pode ser utilizado a fim de otimizar a alocação dos recursos públicos destinados à saúde é o princípio do mínimo existencial. Por meio de sua aplicação seria possível direcionar os recursos públicos disponíveis para o atendimento das prestações de saúde consideradas indispensáveis para o reestabelecimento ou manutenção da saúde do paciente. ${ }^{145}$

Ocorre que esse parâmetro não pode ser utilizado individualmente sob pena de se violar o princípio da equidade, expresso na Constituição Federal no art. 196, que prevê que o Estado deve adotar políticas sociais e econômicas que visem o acesso universal e igualitário à saúde. ${ }^{146}$ Todos, sem discriminação de raça, etnia ou sexo "merecem igualdade de respeito e consideração do Estado quando este elabora e implementa as políticas de saúde" $" 147$.

Dessa forma, propõe-se a adoção de mais um parâmetro para nortear a alocação dos recursos destinados à saúde: a interpretação desse direito fundamental à luz do princípio da equidade.

\footnotetext{
${ }^{145}$ BARCELLOS, Ana Paula de. A eficácia jurídica dos princípios constitucionais: O princípio da dignidade da pessoa humana. $-3^{\mathrm{a}}$ ed. Revista e atualizada. -Rio de Janeiro: Renovar, 2011, p. 324-326.

${ }^{146}$ FERRAZ, Octávio Luiz Motta; VIEIRA, Fabiola Sulpino. Direito à saúde, recursos escassos e equidade: os riscos da interpretação judicial dominante. DADOS-Revista de Ciências Sociais, Rio de Janeiro, v. 52, n. 1, p. 223-251, Mar. 2009. p. 239. Disponível em: $<$ http://www.scielo.br/scielo.php?script=sci_arttext\&pid=S001152582009000100007\&lng=en\&nrm=i so >. Acesso em: 12.04.2019.

${ }^{147}$ FERRAZ, Octávio Luiz Motta; VIEIRA, Fabiola Sulpino. Direito à saúde, recursos escassos e equidade: os riscos da interpretação judicial dominante. DADOS-Revista de Ciências Sociais, Rio de Janeiro, v. 52, n. 1, p. 223-251, Mar. 2009. p. 239. Disponível em: $<$ http://www.scielo.br/scielo.php?script=sci_arttext\&pid=S001152582009000100007\&lng=en\&nrm=i so $>$. Acesso em: 12.04.2019.
} 
O princípio da equidade consiste no reconhecimento de que "os indivíduos são diferentes entre si e, portanto, merecem tratamento diferenciado, de modo a eliminar/ reduzir as desigualdades existentes"148. Assim, sob a perspectiva das políticas de saúde, elas devem visar reduzir ou eliminar as diferenças existentes a fim de criar condições igualitárias de acesso ao direito fundamental. Nesse sentido:

"A questão central a ser tratada pelas políticas que almejam equidade em saúde é a redução ou eliminação das diferenças que advêm de fatores considerados evitáveis e injustos, criando, desse modo, igual oportunidade em saúde e reduzindo as diferenças injustas tanto quanto possível." ${ }^{\text {"149 }}$

O Comitê de Especialistas das Nações Unidas para os Direitos Econômicos, Sociais e Culturais, ao interpretar o art. 12 do Pacto Internacional, corrobora com esse entendimento pois ressalta:

“O direito à saúde não deve ser entendido como o direito a ser saudável. O direito à saúde inclui liberdades e direitos. [...] Por outro lado, entre os direitos figura o direito a um sistema de proteção da saúde, que proporciona às pessoas oportunidades iguais para gozar do melhor estado de saúde possível de se atingir"150

Diante disso, tendo em vista a limitação dos recursos públicos, que impede que se dê "tudo a todos", para que se alcance o ideal de equidade no Brasil as políticas e programas de saúde devem levar em consideração "informações

\footnotetext{
${ }^{148}$ NUNES, André. A alocação equitativa inter-regional de recursos públicos federais do SUS: a receita própria do município como variável moderadora. Relatório de Consultoria (Contrato $\mathrm{n}^{\mathrm{o}}$ 130/2003)-Projeto 1.04.21. Consolidação do Sistema de Informações Sobre Orçamentos Públicos em Saúde-SIOPS. Brasília: Set. 2004.p. 09. Disponível em: $<$ http://siops.datasus.gov.br/documentacao/aloc_equitativa_siops.pdf $>$. Acesso em: 12.04.2019.

${ }^{149}$ VIANA, Ana Luiza d'Ávila; FAUSTO, Márcia Cristina Rodrigues; LIMA, Luciana Dias de. Política de saúde e eqüidade. São Paulo Perspec., São Paulo, v. 17, n. 1, p. 58-68, Mar. 2003. p. 59. Disponível em: $\quad<$ http://www.scielo.br/scielo.php?script=sci_arttext\&pid=S0102$88392003000100007 \& \operatorname{lng}=$ en\&nrm $=$ iso $>$. Acesso em 25.04.2019.

${ }^{150}$ Compilação de Instrumentos Internacionais de Direitos Humanos. Provedoria dos Direitos Humanos e Justiça: Primeira Edição. p. 151. Disponível em: < $\underline{\text { http://acnudh.org/wp- }}$ content/uploads/2011/06/Compilation-of-HR-instruments-and-general-comments-2009-PDHJTimorLeste-portugues.pdf. $>$. Acesso em 25.04.2019.
} 
sobre determinantes sociais em saúde"151 para que assistam de forma mais prioritária aquelas pessoas que estão à mercê das ações do Estado. ${ }^{152}$

O Poder Judiciário, atuando de forma residual, não deve adotar um conceito unidimensional de saúde e deve atentar para as políticas já existentes, sem deixar de ignorar que não há recursos suficientes para se implementar o direito fundamental universalmente de forma ilimitada. ${ }^{153}$ Caso desconsidere o fator da escassez de recursos que impede a implementação do direito à saúde de forma universal e ilimitada, violará o princípio da equidade. ${ }^{154}$ Isso, pois o acesso ao Poder Judiciário ainda é restrito na sociedade brasileira. Assim, o uso desse mecanismo para a obtenção de prestações de saúde favorece uma parcela da população mais abonada, que pode recorrer à judicialização.

\footnotetext{
${ }^{151}$ FERRAZ, Octávio Luiz Motta; VIEIRA, Fabiola Sulpino. Direito à saúde, recursos escassos e equidade: os riscos da interpretação judicial dominante. DADOS-Revista de Ciências Sociais, Rio de Janeiro, v. 52, n. 1, p. 223-251, Mar. 2009. p. 244. Disponível em: $<$ http://www.scielo.br/scielo.php?script $=$ sci arttext\&pid $=$ S001152582009000100007\&lng $=$ en\&nrm $=\mathrm{i}$ so>. Acesso em: 12.04.2019.

${ }^{152}$ FERRAZ, Octávio Luiz Motta; VIEIRA, Fabiola Sulpino. Direito à saúde, recursos escassos e equidade: os riscos da interpretação judicial dominante. DADOS-Revista de Ciências Sociais, Rio de Janeiro, v. 52, n. 1, p. 223-251, Mar. 2009. p. 245. Disponível em:

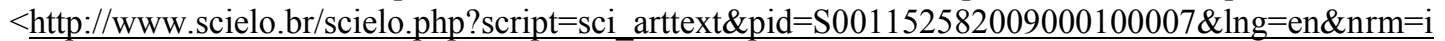
so.> Acesso em: 12.04.2019.

${ }^{153}$ FERRAZ, Octávio Luiz Motta; VIEIRA, Fabiola Sulpino. Direito à saúde, recursos escassos e equidade: os riscos da interpretação judicial dominante. DADOS-Revista de Ciências Sociais, Rio de Janeiro, v. 52, n. 1, p. 223-251, Mar. 2009. p. 242. Disponível em:

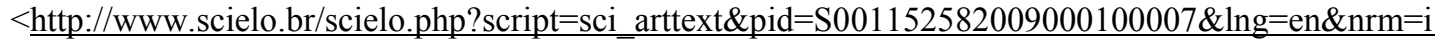
so.> Acesso em: 12.04.2019.

${ }^{154}$ FERRAZ, Octávio Luiz Motta; VIEIRA, Fabiola Sulpino. Direito à saúde, recursos escassos e equidade: os riscos da interpretação judicial dominante. DADOS-Revista de Ciências Sociais, Rio de Janeiro, v. 52, n. 1, p. 223-251, Mar. 2009. p. 242-243. Disponível em: $<\underline{\text { http://www.scielo.br/scielo.php?script=sci_arttext\&pid=S001152582009000100007\&lng }=\text { en\&nrm }=\mathrm{i}}$ so>. Acesso em: 12.04.2019.
} 


\subsection{A independência do Poder Executivo: respeito às políticas públicas}

O Estado Social Democrático exige uma orientação finalística da ação governamental, ou seja, impõe um planejamento estratégico com a eleição de fins ou objetivos comuns e a escolha de meios ou instrumentos para a sua consecução. ${ }^{155}$ Deve ser reorganizada a atividade estatal para que sejam atingidas finalidades coletivas, com destaque para a criação de condições básicas para o alcance da igualdade social. ${ }^{156}$

Assim, a legitimidade do Estado deixa de se fundar na expressão legislativa popular e passa a estar atrelada à realização das finalidades coletivas. ${ }^{157} \mathrm{~A}$ lei perde seu papel de destaque e se torna um instrumento de governo. ${ }^{158}$ Ela deixa de servir para declarar direitos e deveres em situações jurídicas permanentes e passa a solucionar "questões de conjuntura", direcionar a atividade privada e regular procedimentos administrativos. ${ }^{159}$

\footnotetext{
${ }^{155}$ COMPARATO, Fábio Konder. Ensaio sobre o juízo de constitucionalidade de políticas públicas. Revista de Informação Legislativa, Brasília, $\mathrm{n}^{\circ}$ 138, ano 35, p. 39-48, abril/junho 1988. p.43. Disponível em: $<$ http://www2.senado.leg.br/bdsf/bitstream/handle/id/496870/RIL138.pdf?sequence=1\#page=37. . . Acesso em: 15.04.2019.

${ }^{156}$ COMPARATO, Fábio Konder. Ensaio sobre o juízo de constitucionalidade de políticas públicas. Revista de Informação Legislativa, Brasília, $\mathrm{n}^{\circ} 138$, ano 35, p. 39-48, abril/junho 1988. p.43. Disponível http://www2.senado.leg.br/bdsf/bitstream/handle/id/496870/RIL138.pdf?sequence=1\#page=37.. . Acesso em: 15.04.2019.

${ }^{157}$ COMPARATO, Fábio Konder. Ensaio sobre o juízo de constitucionalidade de políticas públicas. Revista de Informação Legislativa, Brasília, $\mathrm{n}^{\circ}$ 138, ano 35, p. 39-48, abril/junho 1988. p.44. Disponível $\mathrm{em}:<$ http://www2.senado.leg.br/bdsf/bitstream/handle/id/496870/RIL138.pdf? sequence=1\#page=37.. . Acesso em: 15.04.2019.

${ }^{158}$ COMPARATO, Fábio Konder. Ensaio sobre o juízo de constitucionalidade de políticas públicas. Revista de Informação Legislativa, Brasília, $\mathrm{n}^{\mathrm{o}}$ 138, ano 35, p. 39-48, abril/junho 1988. p.45. Disponível

http://www2.senado.leg.br/bdsf/bitstream/handle/id/496870/RIL138.pdf? sequence=1\#page=37. . . Acesso em: 15.04.2019.

${ }^{159}$ COMPARATO, Fábio Konder. Ensaio sobre o juízo de constitucionalidade de políticas públicas. Revista de Informação Legislativa, Brasília, $\mathrm{n}^{\circ} 138$, ano 35, p. 39-48, abril/junho 1988. p.45. Disponível $\mathrm{em}:<$ http://www2.senado.leg.br/bdsf/bitstream/handle/id/496870/RIL138.pdf? sequence=1\#page=37. . . Acesso em: 15.04.2019.
} 
Nesse contexto, a política, compreendida como "um conjunto organizado de normas e atos tendentes à realização de um objetivo determinado" ${ }^{160}$, ganha papel de destaque. Ela passa a servir como instrumento da Administração Pública para a consecução dos objetivos previstos nas Constituições. Nesse sentido, Ana Paula de Barcellos ressalta que:

“[...] apenas por meio das políticas públicas o Estado poderá, de forma sistemática e abrangente, realizar os fins previstos na Constituição (e muitas vezes detalhados pelo legislador), sobretudo no que diz respeito aos direitos fundamentais que dependam de ações para a sua promoção". ${ }^{161}$

Note-se que os recursos financeiros disponíveis ao Estado para a realização de políticas públicas são limitados. Assim, as opções constitucionais direcionam a alocação dos recursos pois discriminam os fins a serem perseguidos em caráter prioritário. ${ }^{162}$ De acordo com as escolhas feitas pelo Poder Público os fins podem ser atingidos de forma mais ou menos eficiente. ${ }^{163}$

\subsubsection{Parâmetros de Controle das Políticas Públicas}

Tendo em vista que toda ação estatal deve estar vinculada à

\footnotetext{
${ }^{160}$ COMPARATO, Fábio Konder. Ensaio sobre o juízo de constitucionalidade de políticas públicas. Revista de Informação Legislativa, Brasília, $\mathrm{n}^{\circ}$ 138, ano 35, p. 39-48, abril/junho 1988. p.45. Disponível

http://www2.senado.leg.br/bdsf/bitstream/handle/id/496870/RIL138.pdf?sequence=1\#page=37.. . Acesso em: 15.04.2019.

${ }^{161}$ BARCELOS, Ana Paula de. Neoconstitucionalismo, Direitos fundamentais e controle das políticas públicas. Revista de Direito Administrativo, Rio de Janeiro, v. 240, p. 83-105, abr. 2005. p.90. Disponível em: $\leq$ http://bibliotecadigital.fgv.br/ojs/index.php/rda/article/view/43620>. Acesso em: 18 04. 2019.

${ }^{162}$ BARCELOS, Ana Paula de. Neoconstitucionalismo, Direitos fundamentais e controle das políticas públicas. Revista de Direito Administrativo, Rio de Janeiro, v. 240, p. 83-105, abr. 2005. p.90. Disponível em: $<$ http://bibliotecadigital.fgv.br/ojs/index.php/rda/article/view/43620>. Acesso em: 18.04.2019.

${ }^{163}$ BARCELOS, Ana Paula de. Neoconstitucionalismo, Direitos fundamentais e controle das políticas públicas. Revista de Direito Administrativo, Rio de Janeiro, v. 240, p. 83-105, abr. 2005. p.91.

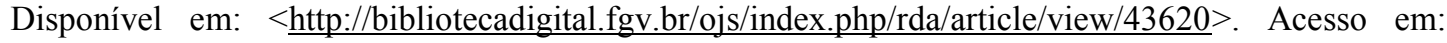
18.04.2019.
} 
Constituição e seus fins, é natural que se entenda que as decisões do Poder Público sobre Políticas Públicas são juridicamente passíveis de controle. ${ }^{164}$

Nesse sentido, Ana Paula de Barcellos traça três tipos de parâmetros que seriam capazes de realizar o controle das políticas públicas: o do objetivo, o do resultado esperado da atuação estatal e o do controle da definição das políticas públicas a serem implementadas. ${ }^{165}$

O parâmetro "objetivo" relaciona-se com a quantidade de recursos que deverá ser aplicado em políticas públicas para que as finalidades constitucionais sejam atingidas. ${ }^{166}$ Para tanto, deve ser apurado o percentual referido pela Constituição em matéria de saúde, levando em consideração a arrecadação de impostos e o valor de receita gerado pelas contribuições. ${ }^{167}$ Em sequência deve ser verificado se os recursos estão sendo alocados em políticas públicas vinculadas aos fins constitucionais. ${ }^{168}$

O parâmetro "resultado esperado da atuação estatal" consiste na identificação dos bens mínimos que devem ser ofertados pelo Estado para a promoção dos direitos fundamentais e da dignidade humana. ${ }^{169}$ Para tanto,

\footnotetext{
${ }^{164}$ BARCELOS, Ana Paula de. Neoconstitucionalismo, Direitos fundamentais e controle das políticas públicas. Revista de Direito Administrativo, Rio de Janeiro, v. 240, p. 83-105, abr. 2005. p.94. Disponível em: $<$ http://bibliotecadigital.fgv.br/ojs/index.php/rda/article/view/43620>. Acesso em: 18.04.2019.

${ }^{165}$ BARCELOS, Ana Paula de. Neoconstitucionalismo, Direitos fundamentais e controle das políticas públicas. Revista de Direito Administrativo, Rio de Janeiro, v. 240, p. 83-105, abr. 2005. p.94-98. Disponível em: $<$ http://bibliotecadigital.fgv.br/ojs/index.php/rda/article/view/43620 $>$. Acesso em: 18.04.2019.

${ }^{166}$ BARCELOS, Ana Paula de. Neoconstitucionalismo, Direitos fundamentais e controle das políticas públicas. Revista de Direito Administrativo, Rio de Janeiro, v. 240, p. 83-105, abr. 2005. p.95-96.

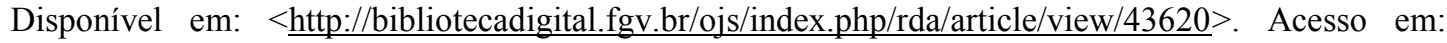
18.04.2019.

${ }^{167}$ BARCELOS, Ana Paula de. Neoconstitucionalismo, Direitos fundamentais e controle das políticas públicas. Revista de Direito Administrativo, Rio de Janeiro, v. 240, p. 83-105, abr. 2005. p.95-96. Disponível em: $<$ http://bibliotecadigital.fgv.br/ojs/index.php/rda/article/view/43620 $>$. Acesso em: 18.04.2019.

${ }^{168}$ BARCELOS, Ana Paula de. Neoconstitucionalismo, Direitos fundamentais e controle das políticas públicas. Revista de Direito Administrativo, Rio de Janeiro, v. 240, p. 83-105, abr. 2005. p.95-96. Disponível em: $<$ http://bibliotecadigital.fgv.br/ojs/index.php/rda/article/view/43620>. Acesso em: 18.04.2019.

${ }^{169}$ BARCELOS, Ana Paula de. Neoconstitucionalismo, Direitos fundamentais e controle das políticas públicas. Revista de Direito Administrativo, Rio de Janeiro, v. 240, p. 83-105, abr. 2005. p.96. Disponível em: $<$ http://bibliotecadigital.fgv.br/ojs/index.php/rda/article/view/43620 $>$. Acesso em: 18.04.2019.
} 
devem ser extraídas das disposições constitucionais "[...] metas concretas a serem atingidas em caráter prioritário pela ação do Poder Público.". ${ }^{170}$ Assim, os recursos devem ser direcionados a políticas capazes de produzir o resultado previsto até ele ser efetivamente alcançado. Enquanto ele não for alcançado, outras políticas públicas não consideradas prioritárias sob a ótica dos dispositivos constitucionais, não poderão ser realizadas. ${ }^{171}$

O parâmetro "controle da definição das políticas públicas a serem implementadas" difere dos anteriores pois ao invés de tratar das metas constitucionais, aborda os meios escolhidos pelo Poder Público para realizálas. ${ }^{172} \mathrm{~A}$ definição dos meios através dos quais as finalidades constitucionais podem ser alcançadas, de acordo com a Constituição, é político-majoritária. ${ }^{173}$ No entanto, não se busca ao criar esse parâmetro permitir a intervenção indiscriminada do Poder Judiciário no Poder Executivo, limitando de forma absoluta as escolhas sobre as Políticas Públicas a serem realizadas. ${ }^{174} \mathrm{Na}$ realidade, busca-se eliminar as possibilidades de escolha das autoridades públicas no que concerne aos meios comprovadamente ineficientes para a

\footnotetext{
${ }^{170}$ BARCELOS, Ana Paula de. Neoconstitucionalismo, Direitos fundamentais e controle das políticas públicas. Revista de Direito Administrativo, Rio de Janeiro, v. 240, p. 83-105, abr. 2005. p.96. Disponível em: $<$ http://bibliotecadigital.fgv.br/ojs/index.php/rda/article/view/43620 $>$. Acesso em: 18.04.2019.

${ }^{171}$ BARCELOS, Ana Paula de. Neoconstitucionalismo, Direitos fundamentais e controle das políticas públicas. Revista de Direito Administrativo, Rio de Janeiro, v. 240, p. 83-105, abr. 2005. p.96.

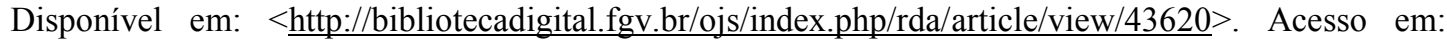
18.04.2019.

${ }^{172}$ BARCELOS, Ana Paula de. Neoconstitucionalismo, Direitos fundamentais e controle das políticas públicas. Revista de Direito Administrativo, Rio de Janeiro, v. 240, p. 83-105, abr. 2005. p.97. Disponível em: $<$ http://bibliotecadigital.fgv.br/ojs/index.php/rda/article/view/43620 >. Acesso em: 18.04.2019

${ }^{173}$ BARCELOS, Ana Paula de. Neoconstitucionalismo, Direitos fundamentais e controle das políticas públicas. Revista de Direito Administrativo, Rio de Janeiro, v. 240, p. 83-105, abr. 2005. p.97. Disponível em: $<$ http://bibliotecadigital.fgv.br/ojs/index.php/rda/article/view/43620>. Acesso em: 18.04.2019

${ }^{174}$ BARCELOS, Ana Paula de. Neoconstitucionalismo, Direitos fundamentais e controle das políticas públicas. Revista de Direito Administrativo, Rio de Janeiro, v. 240, p. 83-105, abr. 2005. p.98.

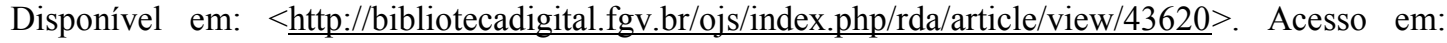
18.04.2019
} 
realização das metas constitucionais. ${ }^{175}$ Assim, seria garantida uma eficiência mínima às Políticas Públicas. Como ressalta Ana Paula de Barcellos:

“As políticas públicas têm de contribuir com uma eficiência mínima para a realização das metas estabelecidas na Constituição, caso contrário, não apenas se estará fraudando as disposições constitucionais, como também desperdiçando recursos

públicos que, como já se sublinhou, são sempre escassos em face das necessidades existentes." 176

\subsubsection{Previsão Orçamentária}

O orçamento público é um mecanismo por meio do qual o Governo Federal pode planejar a utilização do dinheiro arrecadado com tributos. ${ }^{177}$ Esse planejamento assume importância ímpar na medida que permite a oferta de serviços públicos adequados e especifica os gastos e investimentos realizados. ${ }^{178}$ Assim, considerando que as despesas são detalhadas por meio do orçamento, é possível identificar as prioridades do governo para cada ano. ${ }^{179}$

A elaboração do orçamento público envolve três etapas: a aprovação da Lei do Plano Plurianual (PPA), da Lei de Diretrizes Orçamentárias (LDO) e da Lei Orçamentária Anual (LOA). ${ }^{180}$ A iniciativa para a proposição dessas leis é

\footnotetext{
${ }^{175}$ BARCELOS, Ana Paula de. Neoconstitucionalismo, Direitos fundamentais e controle das políticas públicas. Revista de Direito Administrativo, Rio de Janeiro, v. 240, p. 83-105, abr. 2005. p.98. Disponível em: $<$ http://bibliotecadigital.fgv.br/ojs/index.php/rda/article/view/43620 $>$. Acesso em: 18.04.2019

${ }^{176}$ BARCELOS, Ana Paula de. Neoconstitucionalismo, Direitos fundamentais e controle das políticas públicas. Revista de Direito Administrativo, Rio de Janeiro, v. 240, p. 83-105, abr. 2005. p.98.

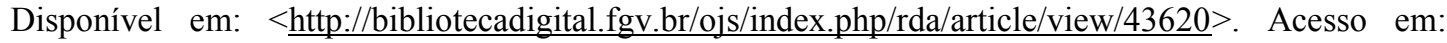
18.04.2019

${ }^{177}$ Portal da Transparência. Controladoria Geral da União. Orçamento Público. Disponível em: $<$ http://www.portaltransparencia.gov.br/entenda-a-gestao-publica/orcamento-publico. $>$. Acesso em 20.04.2019.

${ }^{178}$ Portal da Transparência. Controladoria Geral da União. Orçamento Público. Disponível em: $<$ http://www.portaltransparencia.gov.br/entenda-a-gestao-publica/orcamento-publico. $>$. Acesso em 20.04.2019.

${ }^{179}$ Portal da Transparência. Controladoria Geral da União. Orçamento Público. Disponível em: $<$ http://www.portaltransparencia.gov.br/entenda-a-gestao-publica/orcamento-publico. $>$. Acesso em 20.04.2019.

${ }^{180}$ Portal da Transparência. Controladoria Geral da União. Orçamento Público. Disponível em: $<$ http://www.portaltransparencia.gov.br/entenda-a-gestao-publica/orcamento-publico. $>$. Acesso em 20.04.2019.
} 
do Poder Executivo que, ao elaborar o seu projeto, deve levar em consideração os fins constitucionais. ${ }^{181}$ Ao Congresso Nacional incumbe a aprovação das leis, podendo influenciar no orçamento e adequá-lo às necessidades da população. $^{182}$

A Lei do Plano Plurianual (PPA) declara as políticas, metas previstas e os meios para alcançá-las por um período de 04 anos. ${ }^{183}$

A Lei de Diretrizes Orçamentárias (LDO), por sua vez, determina as metas e prioridades da Lei do Plano Plurianual (PPA) que serão atendidas no ano seguinte. ${ }^{184}$

A partir da aprovação da Lei de Diretrizes Orçamentárias (LDO), é elaborada a Lei Orçamentária Anual (LOA) que detalha os gastos a serem realizados pelo governo no ano seguinte e as receitas, sendo, por isso, considerado um "orçamento anual". ${ }^{185}$

Diante disso, torna-se nítido que essas leis se sucedem e se completam, de forma que "Todos os Planos e Programas nacionais, regionais e setoriais previstos na Constituição devem ser elaborados em consonância com o plano plurianual (art. 165, parágrafo $4^{\circ}$, da CF), e a LDO deverá estar sempre em consonância com o PPA (art. 166, parágrafo $\left.4^{\circ}, \mathrm{CF}\right) . " 186$.

${ }^{181}$ SCAFF, Fernando Facury. Reserva do possível, mínimo existencial e direitos humanos. Verba Juris, ano 4, $\mathrm{n}^{\mathrm{o}}$ 4, p. 79- 104, jan./dez. 2005. p. 91. Disponível em: $<$ http://periodicos.ufpb.br/index.php/vj/article/view/14814>. Acesso em: 21.04.2019.

${ }^{182}$ Portal da Transparência. Controladoria Geral da União. Orçamento Público. Disponível em: $<$ http://www.portaltransparencia.gov.br/entenda-a-gestao-publica/orcamento-publico. $>$. Acesso em 20.04.2019.

${ }^{183}$ Portal da Transparência. Controladoria Geral da União. Orçamento Público. Disponível em: $<$ http://www.portaltransparencia.gov.br/entenda-a-gestao-publica/orcamento-publico. $>$. Acesso em 20.04.2019.

${ }^{184}$ Portal da Transparência. Controladoria Geral da União. Orçamento Público. Disponível em: $<$ http://www.portaltransparencia.gov.br/entenda-a-gestao-publica/orcamento-publico.. . Acesso em 20.04.2019.

${ }^{185}$ Portal da Transparência. Controladoria Geral da União. Orçamento Público. Disponível em: $<$ http://www.portaltransparencia.gov.br/entenda-a-gestao-publica/orcamento-publico. $>$. Acesso em 20.04.2019.

${ }^{186}$ SCAFF, Fernando Facury. Reserva do possível, mínimo existencial e direitos humanos. Verba Juris, ano 4, $\mathrm{n}^{\mathrm{o}}$ 4, p. 79- 104, jan./dez. 2005. p. 91. Disponível em: $<$ http://periodicos.ufpb.br/index.php/vj/article/view/14814>. Acesso em: 21.04.2019. 
Ocorre que, o planejamento econômico viabilizado pela edição das mencionadas leis, apesar de traduzir um modelo de ação, não é neutro pois tem como finalidade a realização de determinados objetivos. ${ }^{187}$ Ou seja, a escolha de objetivos a serem concretizados envolve uma valoração que permite a decisão entre alternativas. ${ }^{188}$

No entanto, ainda que não exista neutralidade no planejamento econômico, a intervenção mais incisiva do setor público sobre "o processo econômico" a fim de permitir a realização dos fins constitucionais não deve ser vista como incompatível com a liberdade. ${ }^{189}$ Nesse sentido, Eros Grau ensina:

"A liberdade, tal qual hoje a concebemos, tem o seu conceito elaborado desde uma visão social e apenas se realiza- na expressão de Carl Landauer - na medida em que dependa da organização social, quando se obtenha a combinação entre um alto grau de segurança econômica para o indivíduo com o máximo de garantias de liberdade pessoal. É imprescindível, assim, que o Estado a todos assegure a possibilidade de serem livres, ou seja, de condições mínimas de subsistência e de igualdade de oportunidades econômicas." $" 190$

Assim, tendo em vista que o direito à saúde envolve prestações que compõem o mínimo existencial, ou seja, prestações materiais indispensáveis para assegurar uma existência digna, condição sine qua non para o exercício da liberdade, é possível vislumbrar a necessidade de uma intervenção mais incisiva do setor público sobre o orçamento.

Nesse sentido, com o intuito de instituir gastos mínimos no Setor de Saúde, a Constituição Federal de 1988 e a Lei Complementar 141/2012 estabeleceram critérios a serem observados pelos entes da federação: A União, nos termos do art. 198, parágrafo $2^{\circ}$, I da CF/1988 e art. $7^{\circ}$ da Lei

\footnotetext{
${ }^{187}$ GRAU, Eros Roberto. Planejamento econômico e regra jurídica / Eros Roberto Grau- São Paulo: Ed. Revista dos Tribunais, 1978. p. 40.

${ }^{188}$ GRAU, Eros Roberto. Planejamento econômico e regra jurídica / Eros Roberto Grau- São Paulo: Ed. Revista dos Tribunais, 1978. p. 40.

${ }^{189}$ GRAU, Eros Roberto. Planejamento econômico e regra jurídica / Eros Roberto Grau- São Paulo: Ed. Revista dos Tribunais, 1978. p. 41.

${ }^{190}$ GRAU, Eros Roberto. Planejamento econômico e regra jurídica / Eros Roberto Grau- São Paulo: Ed. Revista dos Tribunais, 1978. p. 43-44.
} 
Complementar 141/2012, deve alocar no setor de saúde o valor mínimo referente aos investimentos do ano anterior mais o percentual correspondente à variação nominal do PIB; os Estados, nos termos do art. 195, parágrafo $2^{\circ}$, II, da CF/1988 e do art. $6^{\circ}$ da Lei Complementar 141/2012, devem direcionar 12\% de sua receita tributária anual para o setor de saúde; os Municípios, nos termos do art. 198, parágrafo $2^{\circ}$, da $\mathrm{CF} / 1988$, e do art. $7^{\circ}$ da Lei Complementar $141 / 2012$, devem destinar 15\% da receita tributária anual para o setor de saúde e o Distrito Federal, nos termos dos artigos $6^{\circ}$ a $8^{\circ}$ da Lei Complementar 141/2012, deve destinar $12 \%$ da receita correspondente à competência tributária estadual e $15 \%$ da receita correspondente à competência tributária municipal.

É importante observar que a Lei Complementar 141/2012, em seu artigo $3^{\circ}$, conceitua quais são as despesas que podem ser contabilizadas pelos entes da federação para que atinjam o mínimo legal que deve ser destinado ao setor de saúde. De acordo com esse dispositivo legal, despesas relacionadas a vigilância em saúde, atenção integral e universal à saúde, capacitação do pessoal do SUS, desenvolvimento científico, tecnológico e de controle de qualidade, produção, aquisição e distribuição de insumos dos serviços do SUS, saneamento básico, manejo ambiental para controle de doenças, investimentos na ampliação da rede física do SUS, ações de apoio administrativo imprescindíveis à execução de ações e serviços de saúde e a gestão do serviços e operação a rede de saúde pública, são contabilizadas.

Considerando a relevância da destinação de recursos ao setor de saúde, a Constituição Federal estabelece no art. 34, VII, a possibilidade de a União intervir na administração dos Estados da Federação que deixarem de cumprir com a destinação mínima. Os Estados da Federação, por sua vez, podem intervir nos municípios que não destinarem os recursos mínimos previstos às ações e serviços de saúde pública, nos termos do art. 35, III, da Constituição Federal. 


\subsubsection{Orçamento Participativo}

Com o intuito de permitir uma ampla participação da população no processo decisório sobre políticas públicas e promover a transparência e a responsabilidade dos governantes e gestores públicos, surgiu com o movimento brasileiro de redemocratização a ideia de descentralização da administração pública. ${ }^{191}$ Ela permite a aproximação do governo com a comunidade ao possibilitar o atendimento de demandas coletivas e individuais. ${ }^{192}$ Assim, os recursos sociais e econômicos são alocados de forma mais efetiva.

Nesse contexto, o Orçamento Participativo surge como um instrumento de promoção da governança urbana na medida que permite a participação das comunidades no processo decisório das políticas públicas locais. ${ }^{193}$ Assim, segmentos de menor renda podem "ter voz" sobre as prioridades de investimentos em suas comunidades.

Isso é possível pois, de acordo com Boaventura de Souza Santos, o Orçamento Participativo "é uma estrutura e um processo de participação comunitária" que se baseia nos seguintes princípios: todos os cidadãos têm o direito de participar em igual hierarquia, mesmo que não integrem organizações comunitárias; a participação é viabilizada por meio de regras de democracia direta e representativa que compõem um regimento interno criado pelos participantes e os recursos de investimento têm a sua distribuição

\footnotetext{
${ }^{191}$ SOUZA, CELINA. Construção e consolidação de instituições democráticas: papel do orçamento participativo. São Paulo em Perspectiva, São Paulo, v. 15, n. 4, p. 84-97, Dez. 2001. p. 84. Disponível em: $<$ http://www.scielo.br/scielo.php?script=sci arttext\&pid=S010288392001000400010\&lng=en\&nrm=iso $>$. Acesso em: 25.04.2019.

${ }^{192}$ SOUZA, CELINA. Construção e consolidação de instituições democráticas: papel do orçamento participativo. São Paulo em Perspectiva, São Paulo, v. 15, n. 4, p. 84-97, Dez. 2001. p. 84. Disponível em: $<$ http://www.scielo.br/scielo.php?script=sci_arttext\&pid=S0102$88392001000400010 \& \operatorname{lng}=$ en\&nrm=iso $>$. Acesso em: 25.04 .2019 .

${ }^{193}$ SOUZA, CELINA. Construção e consolidação de instituições democráticas: papel do orçamento participativo. São Paulo em Perspectiva, São Paulo, v. 15, n. 4, p. 84-97, Dez. 2001. p. 88. Disponível em: $<$ http://www.scielo.br/scielo.php?script=sci_arttext\&pid=S0102$\underline{88392001000400010 \& \operatorname{lng}=\mathrm{en} \& \mathrm{nrm}=\mathrm{iso}}>$. Acesso em: 25.04.2019.
} 
realizada por meio de um método objetivo que combina "critérios gerais" e “critérios técnicos" definidos pelo Poder Executivo e pelas normas jurídicas. ${ }^{194}$

Assim, por meio dessa organização, o Orçamento Participativo permite uma gestão conjunta de recursos públicos na medida em que permite "decisões partilhadas sobre a distribuição dos fundos orçamentários e de responsabilização administrativa no que diz respeito à efetiva implementação dessas decisões"

A tomada de decisão em que se baseia o Orçamento Participativo tem como fundamento regras gerais e critérios de justiça distributiva aprovados por órgãos institucionais de representação em que a classe popular tem representação majoritária.

Dessa forma, a negociação assume papel de destaque, pois as organizações comunitárias deixam de atuar na lógica de uma cultura de protesto e confrontação e passam a expor as suas ideias sobre o que deve ser incluído no Plano de Investimento. ${ }^{196}$ Essa apresentação de ideias é relevante, pois ela influencia na pontuação obtida por cada região que é convertida na percentagem de recursos de investimentos destinada a ela. ${ }^{197} \mathrm{O}$ sistema de pontos permite a hierarquização das prioridades e permite a alocação de recursos e realização de investimentos de forma mais fidedigna ao desejo expresso pela população. ${ }^{198}$

\footnotetext{
${ }^{194}$ SANTOS, Boaventura de Sousa. Democratizar a democracia: os caminhos da democracia participativa/ Boaventura de Sousa Santos, organizador.- Rio de Janeiro: Civilização Brasileira, 2002. p.467.

${ }^{195}$ SANTOS, Boaventura de Sousa. Democratizar a democracia: os caminhos da democracia participativa/ Boaventura de Sousa Santos, organizador.- Rio de Janeiro: Civilização Brasileira, 2002. p.471.

${ }^{196}$ SANTOS, Boaventura de Sousa. Democratizar a democracia: os caminhos da democracia participativa/ Boaventura de Sousa Santos, organizador.- Rio de Janeiro: Civilização Brasileira, 2002. p.512-513.

${ }^{197}$ SANTOS, Boaventura de Sousa. Democratizar a democracia: os caminhos da democracia participativa/ Boaventura de Sousa Santos, organizador.- Rio de Janeiro: Civilização Brasileira, 2002. p. 513.

${ }^{198}$ SANTOS, Boaventura de Sousa. Democratizar a democracia: os caminhos da democracia participativa/ Boaventura de Sousa Santos, organizador.- Rio de Janeiro: Civilização Brasileira, 2002. p.513.
} 
Diante disso, torna-se nítido que é instituída através do Orçamento Participativo uma autonomia relativa: o poder político é partilhado com uma rede de instituições democráticas que visam obter decisões por meio de deliberação. ${ }^{199}$ Assim, ele é instrumento que pode viabilizar uma distribuição mais equânime dos gastos com as políticas sociais.

Nesse sentido, o Orçamento Participativo pode ser um instrumento satisfatório para a viabilização da realização das políticas de saúde. Isso, porque através dele podem ser alocados recursos de forma a garantir "todo o conjunto de prestações materiais indispensáveis para assegurar a cada pessoa uma vida condigna, no sentido de vida saudável”200. Assim, a invocação da reserva do possível para eximir o Estado da promoção dos direitos que compõem o mínimo existencial se tornaria descabida nos casos em que o orçamento prevê gastos com essa finalidade. Nessas hipóteses não existiria limite fático e nem jurídico à efetivação jurídica e política dos direitos fundamentais.

\footnotetext{
${ }^{199}$ SANTOS, Boaventura de Sousa. Democratizar a democracia: os caminhos da democracia participativa/ Boaventura de Sousa Santos, organizador.- Rio de Janeiro: Civilização Brasileira, 2002. p.526.

${ }^{200}$ SARLET, I.; FIGUEIREDO, M. Reserva do possível, mínimo existencial e direito à saúde. Revista Brasileira de Direitos Fundamentais \& Justiça, v. 1, n. 1, p. 171-213, 25 mar. 2007. p. 184.

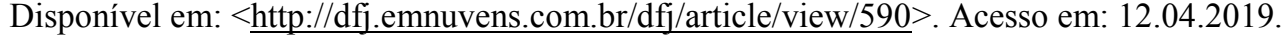




\section{Capítulo IV - Medidas para a efetivação do Direito à Saúde}

Em 2009 o Supremo Tribunal Federal convocou uma Audiência Pública de Saúde aberta à sociedade civil e com a participação de especialistas "objetivando esclarecer as questões técnicas, científicas, administrativas, políticas, econômicas e jurídicas relativas às ações de prestação de saúde" ${ }^{201}$. Através dela acreditava-se que seria possível levar ao poder judiciário diferentes perspectivas sobre o direito à saúde no Brasil. ${ }^{202}$

Diante das questões suscitadas nos debates realizados na Audiência Pública de Saúde, o Conselho Nacional de Justiça elegeu o tema “judicialização da saúde" para um programa de ação. ${ }^{203}$ Assim, foi eleito um grupo de trabalho que deveria estudar mais a fundo o direito à saúde e o papel do poder judiciário na sua efetivação, para que fossem propostas medidas em relação as demandas judiciais existentes. ${ }^{204}$

Foram fruto desse trabalho realizado pelo Conselho Nacional de Justiça a Resolução $\mathrm{n}^{\circ}$ 107, de 2010, a Recomendação $\mathrm{n}^{0}$ 31, de 2010, e a Recomendação ${ }^{\circ}$ 36. de 2011.

A Resolução n 107, de 2010, do Conselho Nacional de Justiça instituiu o Fórum Nacional da Saúde para o monitoramento e resolução das demandas de assistência de saúde. A partir do monitoramento por ele realizado seria

\footnotetext{
${ }^{201}$ Despacho de Convocação da Audiência Pública de Saúde (05.03.2009). Disponível em: $<$ http://www.stf.jus.br/arquivo/cms/processoAudienciaPublicaSaude/anexo/Despacho_Convocatorio.p df. >. Acesso em: 15.05.2019.

${ }^{202}$ DUARTE, Vanessa Genicia. Arranjos e Diálogos Institucionais para Enfrentamento da Judicialização da Saúde: uma análise dos modelos de assessoramento técnico (NAT's). Limeira/SP. 2017. 114 p. Dissertação de Mestrado. Comissão de Pós-Graduação Interdisciplinar em Ciências Humanas e Sociais Aplicadas. Universidade Estadual de Campinas (UNICAMP). p.57

${ }^{203}$ DUARTE, Vanessa Genicia. Arranjos e Diálogos Institucionais para Enfrentamento da Judicialização da Saúde: uma análise dos modelos de assessoramento técnico (NAT's). Limeira/SP. 2017. 114 p. Dissertação de Mestrado. Comissão de Pós-Graduação Interdisciplinar em Ciências Humanas e Sociais Aplicadas. Universidade Estadual de Campinas (UNICAMP). p.57

${ }^{204}$ DUARTE, Vanessa Genicia. Arranjos e Diálogos Institucionais para Enfrentamento da Judicialização da Saúde: uma análise dos modelos de assessoramento técnico (NAT's). Limeira/SP. 2017. 114 p. Dissertação de Mestrado. Comissão de Pós-Graduação Interdisciplinar em Ciências Humanas e Sociais Aplicadas. Universidade Estadual de Campinas (UNICAMP). p.57
} 
possível captar medidas concretas e normativas voltadas para a efetividade dos processos e para a prevenção de conflitos judiciais. ${ }^{205}$

Já a Recomendação $n^{0}$ 31, de 2010, do Conselho Nacional de Justiça, considerando o grande número de demandas que envolvem o direito à saúde em trâmite e a relevância da matéria para a garantia de vida digna da população brasileira, visa a criação de medidas concretas para a o aperfeiçoamento das decisões judiciais. Assim, propõe que sejam celebrados convênios com setores e instituições estranhas ao poder judiciário que sejam capazes de subsidiar os magistrados na "formação de um juízo de valor quanto à apreciação das questões clínicas apresentadas pelas partes das ações relativas à saúde [...]”206 . Além disso, a Recomendação traça diretrizes para a atuação dos magistrados quando diante de situações que envolvem prestações de saúde como, por exemplo: (i) a necessidade de determinação, no momento da concessão de medida abrangida por política pública existente, da inscrição do beneficiário nos respectivos programas; (ii) a oitiva de gestores antes da aplicação de medidas de urgência.

A Resolução $\mathrm{n}^{\circ} 36$ do Conselho Nacional de Justiça, por sua vez, considerando a relevância pública das ações e serviços de saúde, recomenda aos Tribunais de Justiça dos Estados e Tribunais Regionais Federais que celebrem convênios para que tenham apoio técnico de médicos e farmacêuticos indicados pelos Comitês Executivos Estaduais. Dessa forma, os magistrados teriam auxílio para formar seu convencimento nas demandas que envolvem o direito à saúde.

Diante do teor dos atos normativos do Conselho Nacional de Justiça, em diversos Estados surgiram iniciativas que visam a prevenção dos conflitos judiciais e o aperfeiçoamento e maior eficiência das decisões judiciais nas demandas que envolvem o direito à saúde. São exemplos de iniciativas os

\footnotetext{
${ }^{205}$ Resolução n ${ }^{\mathrm{o}} 107$ de 06.04.2010 do Conselho Nacional de Justiça.

${ }^{206}$ Recomendação n ${ }^{\circ} 31$ de 30.03.2010 do Conselho Nacional de Justiça.
} 
Núcleos de Assessoramento Técnico e as Câmaras de Resolução de Litígios de Saúde.

Os Conselhos de Saúde, apesar de já existirem no país desde os anos 90, têm o seu papel revisitado e reavaliado nesse contexto, na medida que passam a ser vistos como instrumentos de social accountability ${ }^{207} .^{208}$

\subsection{Núcleos de Assessoramento Técnico (NAT)}

A crescente judicialização de demandas envolvendo prestações de saúde e o desequilíbrio do orçamento público passaram a exigir dos magistrados saberes técnicos da área médica e normativos (relacionados à organização do Sistema Único de Saúde) para a fundamentação das suas decisões. ${ }^{209}$

Diante disso, em atendimento à Recomendação $\mathrm{n}^{\mathrm{o}} 31$ do Conselho Nacional de Justiça, foram criados os Núcleos de Assessoramento Técnico (NAT).

Os Núcleos de Assessoramento Técnico são compostos por uma equipe multidisciplinar que envolve funcionários administrativos, farmacêuticos, nutricionistas, enfermeiros e são coordenados por farmacêuticos e médicos. ${ }^{210} \mathrm{~A}$ esses profissionais incumbe a elaboração de pareceres técnicos embasados no binômio "necessidade/utilidade", a fim de determinar a eficácia do tratamento requerido pelos pacientes e o menor custo para o alcance do

\footnotetext{
${ }^{207}$ O termo "Social Accountability" é utilizado para se referir à responsabilização por controle social.

${ }^{208}$ OLIVEIRA, Valdir de Castro. Comunicação, informação e participação popular nos Conselhos de Saúde. Saude soc., São Paulo, v. 13, n. 2, p. 56-69, ago. 2004. p.63. Disponível em $<$ http://www.scielo.br/scielo.php?script $=$ sci $\operatorname{arttext\& pid=S0104-}$ $12902004000200006 \& \operatorname{lng}=$ pt\&nrm=iso $>$. Acesso em 18.05.2019.

${ }^{209}$ Comitê Estadual de Saúde do Rio de Janeiro. Histórico do NAT. Disponível em: $<$ http://www10.trf2.jus.br/comite-estadual-de-saude-rj/nat-jus/historico/>. Acesso em 19.05.2019.

${ }^{210}$ FERREIRA, Siddharta Legale; COSTA, Aline Matias da. Núcleos de Assessoria Técnica e Judicialização da Saúde: Constitucionais ou Inconstitucionais?. Rev. SJRJ, Rio de Janeiro, v. 2, n. 36, p. 219-240, abr. 2013. p. 221. Disponível em: $<$ http://www.ufjf.br/siddharta_legale/files/2014/07/Nucleos-de-assessoria-tecnica-ejudicializa\%C3\%A7\%C3\%A3o-da-sa\%C3\%BAde.pdf $>$. Acesso em 18.05.2019.
} 
benefício pretendido. ${ }^{211}$ São analisados os documentos contidos no processo, a legislação pertinente e o quadro clínico descrito para que se possa avaliar a indicação, a existência de políticas públicas que atendam o demandante, a possibilidade de alternativa terapêutica, a adequação do quantitativo pleiteado e o quantitativo prescrito, a existência de registro do tratamento ou medicamento na ANVISA, o uso de medicamento para indicações não previstas em bula, medicamentos em fase experimental e medicamentos ou insumos exigidos com marca específica. ${ }^{212}$

Para que isso seja possível os processos encaminhados ao Núcleo de Assessoramento Técnico são cadastrados em um banco de dados e distribuídos à equipe para que possam ser elaborados os pareceres técnicos. ${ }^{213}$ À coordenação do núcleo incumbe a revisão dos pareceres elaborados pela equipe. ${ }^{214}$ Os pareceres, quando finalizados, são enviados ao cartório ou secretaria do juiz que fez o encaminhamento do caso. ${ }^{215}$

Dessa forma, os Núcleos de Assessoramento Técnico têm como função precípua o auxílio aos magistrados no julgamento de questões que envolvem prestações relacionadas ao direito à saúde. Dão suporte técnico para uma

\footnotetext{
${ }^{211}$ FERREIRA, Siddharta Legale; COSTA, Aline Matias da. Núcleos de Assessoria Técnica e Judicialização da Saúde: Constitucionais ou Inconstitucionais?. Rev. SJRJ, Rio de Janeiro, v. 2, n. 36, p. 219-240, abr. 2013. p. 221. Disponível em: $<$ http://www.ufjf.br/siddharta legale/files/2014/07/Nucleos-de-assessoria-tecnica-ejudicializa\%C3\%A7\%C3\%A3o-da-sa\%C3\%BAde.pdf $>$. Acesso em 18.05.2019.

${ }^{212}$ Comitê Estadual de Saúde do Rio de Janeiro. Histórico do NAT. Disponível em: $<$ http://www10.trf2.jus.br/comite-estadual-de-saude-rj/nat-jus/historico/ $>$. Acesso em 19.05.2019.

${ }^{213}$ FERREIRA, Siddharta Legale; COSTA, Aline Matias da. Núcleos de Assessoria Técnica e Judicialização da Saúde: Constitucionais ou Inconstitucionais?. Rev. SJRJ, Rio de Janeiro, v. 2, n. 36, p. 219-240, abr. 2013. p. 221. Disponível em: $<$ http://www.ufjf.br/siddharta legale/files/2014/07/Nucleos-de-assessoria-tecnica-ejudicializa\%C3\%A7\%C3\%A3o-da-sa\%C3\%BAde.pdf $>$. Acesso em 18.05.2019.

${ }^{214}$ FERREIRA, Siddharta Legale; COSTA, Aline Matias da. Núcleos de Assessoria Técnica e Judicialização da Saúde: Constitucionais ou Inconstitucionais?. Rev. SJRJ, Rio de Janeiro, v. 2, n. 36, p. 219-240, abr. 2013. p. 221. Disponível em: $<$ http://www.ufjf.br/siddharta_legale/files/2014/07/Nucleos-de-assessoria-tecnica-ejudicializa\%C3\%A7\%C3\%A3o-da-sa\%C3\%BAde.pdf $>$. Acesso em 18.05.2019.

${ }^{215}$ FERREIRA, Siddharta Legale; COSTA, Aline Matias da. Núcleos de Assessoria Técnica e Judicialização da Saúde: Constitucionais ou Inconstitucionais?. Rev. SJRJ, Rio de Janeiro, v. 2, n. 36, p. 219-240, $a b r .2013 . \quad$ p. 221. Disponível em: $<$ http://www.ufjf.br/siddharta legale/files/2014/07/Nucleos-de-assessoria-tecnica-ejudicializa\%C3\%A7\%C3\%A3o-da-sa\%C3\%BAde.pdf $>$. Acesso em 18.05.2019.
} 
decisão mais realista e fundamentada, mas não vinculam o magistrado. Somente o magistrado, em casos em que o medicamento ou tratamento não está previsto na lista do Sistema Único de Saúde, pode concedê-lo ou não, independente do parecer do Núcleo de Assessoramento Técnico. ${ }^{216}$

No entanto, essa não é a única função desempenhada pelos Núcleos de Assessoramento Técnico. Eles atuam na fase pré-processual, quando buscam uma solução administrativa relativa à prestação de saúde demandada, ${ }^{217} \mathrm{e}$ também servem como filtro de demandas judiciais, pois caso o medicamento demandado pelo paciente se encontre na lista do Sistema Único de Saúde e esteja disponível, é realizado um encaminhamento para que ele o retire. ${ }^{218}$

Dessa forma, os Núcleos de Assessoramento Técnico permitem um atendimento mais ágil aos cidadãos e contribuem para a redução do número de processos judiciais ao buscarem soluções administrativas para as demandas. ${ }^{219}$

Note-se que o Núcleo de Assessoramento Técnico pode ser utilizado como instrumento de gestão das Secretarias de Saúde Estaduais e Municipais na medida que permite a identificação da incidência das demandas. ${ }^{220}$ Assim,

\footnotetext{
${ }^{216}$ FERREIRA, Siddharta Legale; COSTA, Aline Matias da. Núcleos de Assessoria Técnica e Judicialização da Saúde: Constitucionais ou Inconstitucionais?. Rev. SJRJ, Rio de Janeiro, v. 2, n. 36, p. 219-240, abr. 2013. p. 222. Disponível em: $<$ http://www.ufjf.br/siddharta_legale/files/2014/07/Nucleos-de-assessoria-tecnica-ejudicializa\%C3\%A7\%C3\%A3o-da-sa\%C3\%BAde.pdf $>$. Acesso em 18.05.2019.

${ }^{217}$ PINHEIRO, Mariana Carvalho. Núcleos de Assessoramento Técnico: Estratégia à judicialização da Saúde?. Brasília/DF. 2016. 48 p. Monografia apresentada na Escola Nacional de Administração Pública. Disponível em: http://repositorio.enap.gov.br/bitstream/1/2490/1/Mariana\%20Pinheiro.pdf. . . Acesso em: 17.05.2019. p. 4

${ }^{218}$ FERREIRA, Siddharta Legale; COSTA, Aline Matias da. Núcleos de Assessoria Técnica e Judicialização da Saúde: Constitucionais ou Inconstitucionais?. Rev. SJRJ, Rio de Janeiro, v. 2, n. 36, p. 219-240, abr. 2013. p. 221. Disponível em: $<$ http://www.ufjf.br/siddharta legale/files/2014/07/Nucleos-de-assessoria-tecnica-ejudicializa\%C3\%A7\%C3\%A3o-da-sa\%C3\%BAde.pdf $>$. Acesso em 18.05.2019.

${ }^{219}$ PINHEIRO, Mariana Carvalho. Núcleos de Assessoramento Técnico: Estratégia à judicialização da Saúde?. Brasília/DF. 2016. 48 p. Monografia apresentada na Escola Nacional de Administração Pública. Disponível em: http://repositorio.enap.gov.br/bitstream/1/2490/1/Mariana\%20Pinheiro.pdf. . . Acesso em: 17.05.2019. p. 4

${ }^{220}$ PINHEIRO, Mariana Carvalho. Núcleos de Assessoramento Técnico: Estratégia à judicialização da Saúde?. Brasília/DF. 2016. 48 p. Monografia apresentada na Escola Nacional de Administração Pública. 
são coletados dados para que as ações de saúde possam ser planejadas e executadas com maior eficiência, otimizando o atendimento prestado aos usuários. ${ }^{221}$

O primeiro Núcleo de Assessoramento Técnico foi criado em 2009 no Estado do Rio de Janeiro por meio de uma parceria realizada entre o Tribunal de Justiça do Estado do Rio de Janeiro, a Secretaria de Saúde do Estado e a Defesa Civil. Ele foi um modelo de sucesso e, por conta disso, o $\mathrm{STF}^{222}$ e o CNJ passaram a estimular a sua criação em outros estados para que fosse possível a sua oitiva antes da concessão de liminares. Nesse sentido, o Enunciado 18 da $1^{\text {a }}$ Jornada de Direito da Saúde dispõe:

"Sempre que possível, as decisões liminares sobre saúde devem ser precedidas de notas de evidência científica emitidas por Núcleos de Apoio Técnico em Saúde NATS."

\subsection{Câmara de Resolução de Litígios de Saúde}

Diante das desvantagens trazidas pela judicialização do direito à saúde impõe-se a busca de outros meios eficazes de justiça, menos intervencionistas e mais consensuais. ${ }^{223}$ Por meio deles seria possível contemplar a oferta de bens e serviços de saúde à sociedade, não apenas desonerando o erário e contribuindo para a redução de demandas em curso no Poder Judiciário, mas

http://repositorio.enap.gov.br/bitstream/1/2490/1/Mariana\%20Pinheiro.pdf.>. Acesso em: 17.05.2019. p. 4

${ }_{221}$ PINHEIRO, Mariana Carvalho. Núcleos de Assessoramento Técnico: Estratégia à judicialização da Saúde?. Brasília/DF. 2016. 48 p. Monografia apresentada na Escola Nacional de Administração Pública. Disponível em:

http://repositorio.enap.gov.br/bitstream/1/2490/1/Mariana\%20Pinheiro.pdf. . . Acesso em: 17.05.2019. p. 4

${ }_{222}$ Supremo Tribunal Federal, Pedido de Suspensão de Tutela Antecipada $\mathrm{n}^{\circ}$ 175, Relator Ministro Gilmar Mendes, 17.03.2010.

${ }^{223}$ THOMÉ DA CRUZ, Marco Tulio; DE NEZ, Brunna Agostini. A CONTRIBUIÇÃO DA MEDIAÇÃO SANITÁRIA PARA A DESJUDICIALIZAÇÃO DO DIREITO À SAÚDE. Seminário Internacional de Direitos Humanos e Democracia, [S.1.], dez. 2017. p. 8. Disponível em: $<$ https://publicacoeseventos.unijui.edu.br/index.php/direitoshumanosedemocracia/article/view/8658>. Acesso em: 16.05.2019. 
também concretizando de forma mais efetiva o direito fundamental à saúde, garantido pela Constituição de $1988 .^{224}$

Nesse contexto, é fundamental a participação da sociedade civil, dos gestores públicos, médicos, defensores públicos, promotores de justiça, advogados públicos e juízes, ${ }^{225}$ que devem se voltar para a viabilização do atendimento das demandas apresentadas sanando a ineficiência de procedimentos internos das secretarias de saúde, acelerando procedimentos internos demorados, e facilitando a comunicação à justiça quanto ao cumprimento das ordens judiciais. ${ }^{226}$

Destaca-se como iniciativa na área da mediação sanitária o projeto Câmara de Resolução de Litígios de Saúde implementado no Estado do Rio de Janeiro por meio do Convênio de Cooperação n ${ }^{o}$ 003/504/2012, celebrado em 12 de junho de 2012, que reúne a Defensoria Pública Geral do Estado do Rio de Janeiro, a Defensoria Pública da União, o Tribunal de Justiça do Estado do Rio de Janeiro, a Procuradoria Geral do Estado do Rio de Janeiro, a Procuradoria Geral do Município do Rio de Janeiro, a Secretaria de Estado de Saúde do Rio de Janeiro e a Secretaria Municipal de Saúde do Rio de Janeiro. $^{227}$

\footnotetext{
${ }^{224}$ THOMÉ DA CRUZ, Marco Tulio; DE NEZ, Brunna Agostini. A CONTRIBUIÇÃO DA MEDIAÇÃO SANITÁRIA PARA A DESJUDICIALIZAÇÃO DO DIREITO À SAÚDE. Seminário Internacional de Direitos Humanos e Democracia, [S.1.], dez. 2017. p. 8. Disponível em: $<$ https://publicacoeseventos.unijui.edu.br/index.php/direitoshumanosedemocracia/article/view/8658>. Acesso em: 16.05.2019.

${ }^{225}$ THOMÉ DA CRUZ, Marco Tulio; DE NEZ, Brunna Agostini. A CONTRIBUIÇÃO DA MEDIAÇÃO SANITÁRIA PARA A DESJUDICIALIZAÇÃO DO DIREITO À SAÚDE. Seminário Internacional de Direitos Humanos e Democracia, [S.1.], dez. 2017. p. 8. Disponível em: $<$ https://publicacoeseventos.unijui.edu.br/index.php/direitoshumanosedemocracia/article/view/8658>. Acesso em: 16.05.2019.

${ }^{226}$ SOUZA, Anderson Monteiro de. A atuação em rede de instituições governamentais na resolução de conflitos sobre demandas sanitárias no Rio de Janeiro. Rio de Janeiro. 2016. 90 p. Dissertação Mestrado Profissional em Administração Pública - Escola Brasileira de Administração Pública e de Empresas, Fundação Getúlio Vargas - FGV. 2016. Disponível em: $<$ https://bibliotecadigital.fgv.br/dspace/bitstream/handle/10438/16052/Disserta\%C3\%A7\%C3\%A3o_v er final.pdf? sequence=1\&isAllowed=y. $>$. Acesso em: 16.05.2019. p. 35

${ }^{227}$ SOUZA, Anderson Monteiro de. A atuação em rede de instituiçães governamentais na resolução de conflitos sobre demandas sanitárias no Rio de Janeiro. Rio de Janeiro. 2016. 90 p. Dissertação Mestrado Profissional em Administração Pública - Escola Brasileira de Administração Pública e de Empresas, Fundação Getúlio Vargas - FGV. 2016. Disponível em:
} 
O objetivo da Câmara de Resolução de Litígios de Saúde é buscar soluções administrativas que atendam os cidadãos hipossuficientes, assistidos pela Defensoria Pública do Estado ou pela Defensoria Pública da União, ${ }^{228}$ que necessitam de medicamentos, agendamento de procedimento cirúrgico ou clínico, internação, exames médicos, tratamentos e transferência do Sistema Único de Saúde. ${ }^{229}$ Assim, evita-se a judicialização das demandas que envolvem prestações relacionadas ao direito à saúde.

A fim de concretizar esse objetivo os membros das Defensorias Públicas atuam na coordenação dos atendimentos realizados, no processamento dos casos e adotam as medidas extrajudiciais e judiciais necessárias. ${ }^{230}$ Quando agem assim fomentam debates institucionais e auxiliam na implementação de propostas de políticas públicas de saúde. ${ }^{231}$

Os representantes das Secretarias de Saúde realizam um acolhimento humanizado dos assistidos e os orientam, elaboram pareceres, instauram procedimentos de compra e contratação para que as demandas apresentadas sejam sanadas e prestam informações sobre a organização e funcionamento do Sistema Único de Saúde. ${ }^{232}$

$<$ https://bibliotecadigital.fgv.br/dspace/bitstream/handle/10438/16052/Disserta\%C3\%A7\%C3\%A3o_v er final.pdf? sequence=1\&isAllowed=y. $>$. Acesso em: 16.05.2019. p. 35-36.

${ }^{228} \mathrm{ALÔ}$, Bernard dos Reis. Desjudicializando o direito à saúde - O papel da defensoria pública nesse processo. Revista CEJ, Brasília, Ano XX, n. 70, p. 101-112, set./dez. 2016. p. 104. Disponível em: < https://bdjur.stj.jus.br/jspui/bitstream/2011/109626/desjudicializando_direito saude_reis.mht.pdf $>$. Acesso em: 19.05.2019.

${ }^{229}$ Prêmio Innovare- Edição XI- 2014. Câmara de Resolução de Litígios de Saúde-CRLS. Descrição Resumida. Disponível em: $<$ https://www.premioinnovare.com.br/praticas/l/camara-de-resolucao-delitigios-de-saude-crls $>$. Acesso em: 19.05.2019.

${ }^{230}$ ALÔ, Bernard dos Reis. Desjudicializando o direito à saúde - O papel da defensoria pública nesse processo. Revista CEJ, Brasília, Ano XX, n. 70, p. 101-112, set./dez. 2016. p. 104. Disponível em: $<$ https://bdjur.stj.jus.br/jspui/bitstream/2011/109626/desjudicializando_direito_saude_reis.mht.pdf $>$. Acesso em: 19.05.2019.

${ }^{231}$ ALÔ, Bernard dos Reis. Desjudicializando o direito à saúde - O papel da defensoria pública nesse processo. Revista CEJ, Brasília, Ano XX, n. 70, p. 101-112, set./dez. 2016. p. 104. Disponível em:

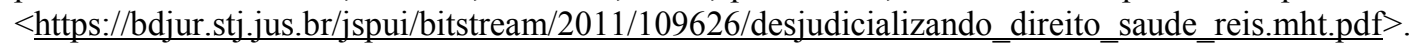
Acesso em: 19.05.2019.

${ }^{232}$ ALÔ, Bernard dos Reis. Desjudicializando o direito à saúde - O papel da defensoria pública nesse processo. Revista CEJ, Brasília, Ano XX, n. 70, p. 101-112, set./dez. 2016. p. 105. Disponível em: $<$ https://bdjur.stj.jus.br/jspui/bitstream/2011/109626/desjudicializando_direito_saude_reis.mht.pdf $>$.

Acesso em: 19.05.2019. 
As Procuradorias do Estado e do Município atuam designando procuradores para a atuação nas sessões de mediação da Câmara e prestando orientação jurídica às Secretarias de Saúde. ${ }^{233}$

O Tribunal de Justiça, por sua vez, designa mediadores, supervisores e coordena as atividades de mediação realizadas na Câmara de Resolução de Litígios de Saúde. ${ }^{234}$

A reunião de todos esses atores estruturalmente em um único órgão permite uma "interlocução extrajudicial entre Instituições essenciais do sistema de justiça" ${ }^{235}$ que potencializa o intercâmbio de informações e permite o atendimento mais eficiente dos assistidos. ${ }^{236}$ Assim, são alcançadas soluções consensuais, que não demandam intervenção judicial, pois as Câmaras de Resolução de Litígios são espaços de diálogo entre as instituições envolvidas na tutela do direito à saúde. ${ }^{237}$

\subsection{Conselhos de Saúde}

$\mathrm{Na}$ estrutura do Sistema Único de Saúde estão previstas instâncias colegiadas deliberativas de questões políticas e técnicas do setor de saúde: os Conselhos de Saúde. Esses órgãos, nos termos da Resolução nº 453, de 10 de

\footnotetext{
${ }^{233}$ ALÔ, Bernard dos Reis. Desjudicializando o direito à saúde - O papel da defensoria pública nesse processo. Revista CEJ, Brasília, Ano XX, n. 70, p. 101-112, set./dez. 2016. p. 105. Disponível em: $<$ https://bdjur.stj.jus.br/jspui/bitstream/2011/109626/desjudicializando_direito_saude reis.mht.pdf $>$. Acesso em: 19.05.2019.

${ }^{234} \mathrm{ALO}$, Bernard dos Reis. Desjudicializando o direito à saúde - O papel da defensoria pública nesse processo. Revista CEJ, Brasília, Ano XX, n. 70, p. 101-112, set./dez. 2016. p. 105. Disponível em:

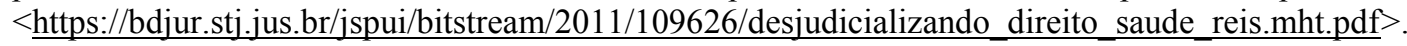
Acesso em: 19.05.2019.

${ }^{235}$ ALÔ, Bernard dos Reis. Desjudicializando o direito à saúde - O papel da defensoria pública nesse processo. Revista CEJ, Brasília, Ano XX, n. 70, p. 101-112, set./dez. 2016. p. 105. Disponível em: $<$ https://bdjur.stj.jus.br/jspui/bitstream/2011/109626/desjudicializando_direito_saude reis.mht.pdf $>$. Acesso em: 19.05.2019.

${ }^{236}$ Prêmio Innovare- Edição XI- 2014. Câmara de Resolução de Litígios de Saúde-CRLS. Descrição Resumida. Disponível em: <https://www.premioinnovare.com.br/praticas/1/camara-de-resolucao-delitigios-de-saude-crls $>$. Acesso em: 19.05.2019.

${ }^{237}$ ALÔ, Bernard dos Reis. Desjudicializando o direito à saúde - O papel da defensoria pública nesse processo. Revista CEJ, Brasília, Ano XX, n. 70, p. 101-112, set./dez. 2016. p. 105. Disponível em: $<$ https://bdjur.stj.jus.br/jspui/bitstream/2011/109626/desjudicializando_direito_saude_reis.mht.pdf $>$. Acesso em: 19.05.2019.
} 
maio de 2012, do Ministério da Saúde, são instâncias colegiadas, deliberativas e permanentes do Sistema Único de Saúde (SUS) em cada esfera do Governo, integrantes do Ministério da Saúde, da Secretaria de Saúde dos Estados, do Distrito Federal e dos Municípios.

O papel precípuo dos Conselhos de Saúde é a participação da comunidade nas políticas públicas e na administração da saúde. ${ }^{238}$ Isso é possível pois a regulamentação prevê para todos eles uma composição paritária, ou seja, metade de seus assentos são de representantes da autoridade setorial, dos profissionais, dos prestadores públicos e privados e das pessoas que trabalham no setor da saúde enquanto a outra metade é integrada por representantes dos usuários dos serviços do SUS. ${ }^{239}$

Dessa forma, as atribuições dos Conselhos de Saúde, exercidas por meio de um Plenário, comissões intersetoriais e grupos de trabalho de conselheiros para ações transitórias ${ }^{240}$, visam: fortalecer a participação e o controle social no Sistema Único de Saúde, mobilizando e articulando a sociedade para a defesa dos princípios constitucionais basilares; uma atuação na formulação e no controle da execução das Políticas de Saúde, inclusive em seus aspectos econômicos e financeiros, com a proposição de estratégias para a aplicação em setores públicos e privados; definir diretrizes para a elaboração dos planos de saúde e deliberar sobre o seu conteúdo. ${ }^{241}$

Para que os Conselhos de Saúde possam cumprir o seu papel as três esferas do Governo garantem a eles autonomia administrativa, dotação orçamentária, autonomia financeira e possibilidade de organização de sua

\footnotetext{
${ }^{238}$ Primeira Diretriz da Resolução no 453 de 10 de maio de 2012 do Ministério da Saúde.

${ }^{239}$ LABRA, Maria Eliana; FIGUEIREDO, Jorge St. Aubyn de. Associativismo, participação e cultura cívica: O potencial dos conselhos de saúde. Ciência \& Saúde Coletiva, São Paulo, v. 7, n. 3, p. 537 547, 2002. p. 541. Disponível em: <https://www.scielosp.org/pdf/csc/2002.v7n3/537-547/pt.>. Acesso em: 20.05.2019.

${ }^{240}$ Quarta Diretriz da Resolução n ${ }^{\circ} 453$ de 10 de maio de 2012 do Ministério da Saúde.

${ }^{241}$ Quarta Diretriz da Resolução no 453 de 10 de maio de 2012 do Ministério da Saúde.
} 
secretaria executiva. ${ }^{242}$ Para tanto, é concedida a necessária infraestrutura e apoio técnico. ${ }^{243}$

Diante disso, observa-se que os Conselhos de Saúde exercem um papel fundamental como instrumento para a efetivação do direito à saúde. Isso é possível pois eles permitem o exercício do controle social sobre a res púbica no setor da saúde ${ }^{244}$, ou seja, que a sociedade influencie nas decisões tomadas pelo Estado. ${ }^{245}$ Ainda, os Conselhos de Saúde permitem o social accountability, ou seja, criam um espaço político em que um ou vários atores sociais podem cobrar publicamente de outros comportamentos transparentes e a adequação de seus atos ao interesse individual, público ou coletivo de acordo com as normas e funções previstas onde atuam. ${ }^{246}$ Dessa forma, autoridades devem prestar contas de seus atos diante dos atores sociais e as instituições públicas podem ser interpeladas, cobradas e questionadas. ${ }^{247}$

\footnotetext{
${ }^{242}$ Quarta Diretriz da Resolução $n^{\circ} 453$ de 10 de maio de 2012 do Ministério da Saúde.

${ }^{243}$ Quarta Diretriz da Resolução no 453 de 10 de maio de 2012 do Ministério da Saúde.

${ }^{244}$ LABRA, Maria Eliana; FIGUEIREDO, Jorge St. Aubyn de. Associativismo, participação e cultura cívica: O potencial dos conselhos de saúde. Ciência \& Saúde Coletiva, São Paulo, v. 7, n. 3, p. 537547, 2002. p. 542. Disponível em: <https://www.scielosp.org/pdf/csc/2002.v7n3/537-547/pt.>. Acesso em: 20.05.2019.

${ }^{245}$ OLIVEIRA, Valdir de Castro. Comunicação, informação e participação popular nos Conselhos de Saúde. Saude soc., São Paulo, v. 13, n. 2, p. 56-69, ago. 2004. p.63. Disponível em $<$ http://www.scielo.br/scielo.php?script=sci_arttext\&pid=S010412902004000200006\&lng=pt\&nrm=is o $>$. Acesso em 18.05.2019.

${ }^{246}$ OLIVEIRA, Valdir de Castro. Comunicação, informação e participação popular nos Conselhos de Saúde. Saude soc., São Paulo, v. 13, n. 2, p. 56-69, ago. 2004. p.63. Disponível em $<$ http://www.scielo.br/scielo.php?script=sci_arttext\&pid=S010412902004000200006\&lng=pt\&nrm=is $\mathrm{o}>$. Acesso em 18.05.2019.

${ }^{247}$ OLIVEIRA, Valdir de Castro. Comunicação, informação e participação popular nos Conselhos de Saúde. Saude soc., São Paulo, v. 13, n. 2, p. 56-69, ago. 2004. p.63. Disponível em $<$ http://www.scielo.br/scielo.php?script=sci_arttext\&pid=S010412902004000200006\&lng=pt\&nrm=is $\underline{\mathrm{o}}>$. Acesso em 18.05.2019.
} 


\section{Conclusão}

É possível perceber que o direito à saúde deve ser observado sob diferentes óticas para que seja efetivado sem ferir a discricionariedade do estado na elaboração do orçamento, a igualdade e a equidade.

Nesse sentido impõe-se um desafio aos magistrados quando eles se deparam com "um doente com rosto, identidade, presença física e história"248 pleiteando em juízo uma prestação de saúde não incluída no mínimo existencial ou autorizada por lei, mas da qual depende para a sua sobrevivência. É preciso que ao conceder o provimento judicial o magistrado esteja atento a todos os elementos fáticos que permeiam o caso concreto, inclusive a limitação do orçamento.

A limitação do orçamento, quando analisada em abstrato, parece ser uma resposta do estado para se eximir da obrigação de garantir um direito fundamental. Ora, o estado brasileiro está compelido a seguir um modelo de atenção à saúde que seja capaz de oferecer da melhor maneira possível o acesso universal ao mais diversificado elenco de ações de saúde. ${ }^{249}$ Isso, no entanto, não afasta o problema da limitação orçamentária: o estado deve gerenciar recursos escassos.

Os magistrados, nesse contexto, têm um poder muito grande, determinam que certa prestação de saúde seja custeada pelo Estado, ou seja, que parte do montante destinado no orçamento às prestações de saúde seja utilizado para o custeio dos tratamentos pleiteados. Isso deve ser visto com cautela, pois pode implicar em uma violação da equidade na medida em que parte dos recursos que seriam destinados às políticas públicas de saúde, dirigidas ao coletivo, acabam sendo gastos para a satisfação de um direito individual. Além disso, deve se levar em conta que o acesso ao Poder

\footnotetext{
${ }^{248}$ BARCELLOS, Ana Paula de. A eficácia jurídica dos princípios constitucionais: O princípio da dignidade da pessoa humana. - $3^{3}$ ed. Revista e atualizada. -Rio de Janeiro: Renovar, 2011, p. 322.

${ }^{249} \mathrm{STF}, \mathrm{RE} \mathrm{n}{ }^{\circ}$ 657718, Rel. Ministro Roberto Barroso, julgado em 22.05.2019 (aguarda-se publicação).
} 
Judiciário ainda é restrito na sociedade brasileira. Assim, o uso desse mecanismo para a obtenção de prestações de saúde favorece uma parcela da população mais abonada, que pode recorrer à judicialização.

Dessa forma, não parece ser possível extrair do direito fundamental à saúde um mandamento juridicamente exigível que imponha o provimento gratuito de todo e qualquer serviço ou prestação médico-farmacêutica desejada por indivíduos em qualquer situação.

Nesse sentido, na ocasião do julgamento do Recurso Extraordinário $\mathrm{n}^{\circ}$ 657718, que fixou tese de repercussão geral sobre o fornecimento de medicamentos pelo Estado, o Ministro Alexandre de Moraes ressaltou que o Poder Judiciário deve evitar ser um desestabilizador do orçamento estatal, até porque a atuação estatal deve ser vinculada ao orçamento. ${ }^{250}$ Deve ser preservada a capacidade do estado de sustentar as suas políticas públicas, o que é prejudicado pela "indústria da judicialização". ${ }^{251}$ Em muitas decisões judiciais deixa ser analisado o cerne da questão: a necessidade de se validar jurídica e constitucionalmente as opções do poder público em priorizar coletivamente o direito à saúde mediante políticas públicas estudadas e planejadas. $^{252}$

Assim, o Orçamento Participativo surge como uma medida capaz de permitir a efetivação do direito à saúde pois prevê a participação popular na elaboração de políticas públicas e na destinação de verbas para o custeio delas. Isto é, como instrumento de promoção da governança urbana, ele permite a participação das comunidades no processo decisório das políticas públicas locais. ${ }^{253}$ Dessa forma, segmentos de menor renda podem "ter voz" sobre as prioridades de investimentos em suas comunidades.

\footnotetext{
${ }^{250} \mathrm{STF}, \mathrm{RE} \mathrm{n}{ }^{\mathrm{o}}$ 657718, Rel. Ministro Roberto Barroso, julgado em 22.05.2019 (aguarda-se publicação). ${ }^{251} \mathrm{STF}, \mathrm{RE} \mathrm{n}^{\mathrm{o}}$ 657718, Rel. Ministro Roberto Barroso, julgado em 22.05.2019 (aguarda-se publicação). ${ }^{252} \mathrm{STF}, \mathrm{RE} \mathrm{n}{ }^{\circ}$ 657718, Rel. Ministro Roberto Barroso, julgado em 22.05.2019 (aguarda-se publicação). ${ }^{253}$ SOUZA, CELINA. Construção e consolidação de instituições democráticas: papel do orçamento participativo. São Paulo em Perspectiva, São Paulo, v. 15, n. 4, p. 84-97, Dez. 2001. p. 88. Disponível em:

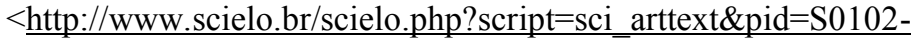
$\underline{88392001000400010 \& \operatorname{lng}=\mathrm{en} \& \mathrm{nrm}=\mathrm{iso}}>$. Acesso em: 25.04.2019.
} 
Também sob a perspectiva inclusiva, os Conselhos de Saúde são órgãos fundamentais na medida que visam a participação da comunidade nas políticas públicas e na administração da saúde. Nesse sentido, a sua composição paritária permite o exercício de controle social sobre a res pública no setor de saúde, influenciando nas decisões tomadas pelo Estado. Além disso, permitem o social accountability na medida que criam um espaço político que permite que os atores sociais cobrem publicamente de outros comportamentos transparentes e a adequação de seus atos.

Tanto a implementação de Orçamentos Participativos quanto a implementação de Conselhos de Saúde contribuem para evitar a judicialização do direito à saúde, pois permitem a observância do direito fundamental sob a ótica da elaboração de políticas públicas. A saúde seria vista como mais do que um direito individual, seria vista como um direito social a ser materializado por meio das políticas públicas realizadas pelo Estado.

Contribui, ainda, para efetivação do direito à saúde, evitando a judicialização, a Câmara de Resolução de Litígios de Saúde. Esse órgão, composto por médicos, gestores públicos, advogados públicos, promotores de justiça e juízes permite uma "interlocução extrajudicial entre Instituições essenciais do sistema de justiça" ${ }^{254}$ que potencializa o intercâmbio de informações e permite o atendimento mais eficiente dos assistidos. ${ }^{255}$ Por meio dele é possível o alcance de soluções consensuais.

Evidente que ainda que esses mecanismos sejam utilizados algumas demandas continuarão a chegar no Poder Judiciário. Em relação a elas será necessário traçar parâmetros decisórios levando em consideração as listas oficiais de dispensação, os protocolos de intervenção terapêutica etc.

\footnotetext{
${ }^{254}$ ALÔ, Bernard dos Reis. Desjudicializando o direito à saúde - O papel da defensoria pública nesse processo. Revista CEJ, Brasília, Ano XX, n. 70, p. 101-112, set./dez. 2016. p. 105. Disponível em: < https://bdjur.stj.jus.br/jspui/bitstream/2011/109626/desjudicializando_direito_saude_reis.mht.pdf>. Acesso em: 19.05.2019.

${ }^{255}$ Prêmio Innovare- Edição XI- 2014. Câmara de Resolução de Litígios de Saúde-CRLS. Descrição Resumida. Disponível em: <https://www.premioinnovare.com.br/praticas/l/camara-de-resolucao-delitigios-de-saude-crls $>$. Acesso em: 19.05.2019.
} 
Nesse sentido, o Supremo Tribunal Federal por ocasião do julgamento do Recurso Extraordinário $n^{\circ}$ 657718, fixou a seguinte tese de repercussão geral:

"1. O Estado não pode ser obrigado a fornecer medicamentos experimentais. 2. A ausência de registro na ANVISA impede, como regra geral, o fornecimento de medicamento por decisão judicial. 3. É possível, excepcionalmente, a concessão judicial de medicamento sem registro sanitário, em caso de mora irrazoável da ANVISA em apreciar o pedido (prazo superior ao previsto na Lei $n^{\circ} 13.411 / 2016$ ), quando preenchidos três requisitos: (i) a existência de pedido de registro do medicamento no Brasil (salvo no caso de medicamentos órfãos para doenças raras e ultrarraras);(ii) a existência de registro do medicamento em renomadas agências de regulação no exterior; e (iii) a inexistência de substituto terapêutico com registro no Brasil. 4. As ações que demandem fornecimento de medicamentos sem registro na ANVISA deverão necessariamente ser propostas em face da União"256

Assim, ficou estabelecido que o Estado, em nenhuma hipótese, pode ser compelido judicialmente a fornecer medicamentos experimentais. Além disso, foram estabelecidos requisitos para que medicamentos sem registro sanitário na ANVISA possam ser objeto de demanda judicial. São critérios objetivos que auxiliam os magistrados quando se deparam com um caso concreto envolvendo o direito à saúde.

Ainda, visando estabelecer certo direcionamento às decisões judiciais que envolvem o direito à saúde, os tribunais do país têm se mobilizado para a criação de Núcleos de Assessoramento Técnico. Esses órgãos dão suporte aos magistrados para a fundamentação de suas decisões quando as demandas envolvem saberes técnicos da área médica e normativos relacionados à organização do SUS.

Dessa forma, é possível concluir que progressivamente busca-se amparar tecnicamente as decisões judiciais e estabelecer critérios objetivos a serem observados pelos magistrados quando diante de questões que envolvam o direito saúde.

\footnotetext{
${ }^{256}$ STF, RE n ${ }^{0} 657718$, Rel. Ministro Roberto Barroso, julgado em 22.05.2019 (aguarda-se publicação).
} 


\section{Bibliografia}

ALEXY, Robert. Teoria dos Direitos Fundamentais. Tradução de Virgílio Afonso da Silva da $5^{a}$ edição alemã Theorie der Grundrechte publicada pela Suhrkamp Velarg (2006). São Paulo: Malheiros Editores, 2008.

ALÔ, Bernard dos Reis. Desjudicializando o direito à saúde - O papel da defensoria pública nesse processo. Revista CEJ, Brasília, Ano XX, n. 70, p. 101-112, set./dez. 2016. Disponível em:

$<$ https://bdjur.stj.jus.br/jspui/bitstream/2011/109626/desjudicializando direito saude reis.mht.pdf $>$. Acesso em: 19.05.2019

BARCELlOS, Ana Paula de. A eficácia jurídica dos princípios constitucionais: O princípio da dignidade da pessoa humana. $-3^{\mathrm{a}}$ ed. revista e atualizada. -Rio de Janeiro: Renovar, 2011.

BARCELOS, Ana Paula de. Neoconstitucionalismo, Direitos fundamentais e controle das políticas públicas. Revista de Direito Administrativo, Rio de Janeiro, v. 240, p. 83-105, abr. 2005. Disponível em:

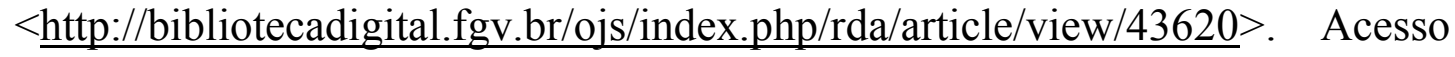
em: 18 04. 2019.

BARLETTA, Fabiana Rodrigues. A pessoa idosa e seu direito prioritário à saúde: Apontamentos a partir do princípio do melhor interesse do idoso. Revista de Direito Sanitário, São Paulo, v. 15, n.1, p. 119-136, mar./jun. 2014. Disponível em: <http://www.revistas.usp.br/rdisan/article/view/82809>. Acesso em: 20.03.2019. 
BARROSO, Luís Roberto. Da falta de efetividade à judicialização excessiva: direito à saúde, fornecimento gratuito de medicamentos e parâmetros para a atuação judicial. Jurisp. Mineira, Belo Horizonte, a. 60, n 188, p. 29-60, jan./mar. 2009. Disponível em:

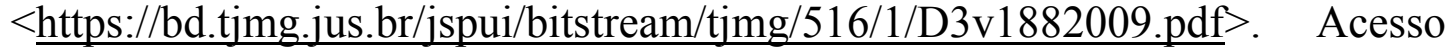
em: 14.03.2019.

BRASIL. Constituição da República Federativa do Brasil de 1988. Disponível em:

$<\underline{\text { http://www.planalto.gov.br/ccivil_03/Constituicao/ConstituicaoCompilado.ht }}$ m>. Acesso em: 01.04.2019.

BRASIL. Decreto $\mathrm{n}^{\mathrm{o}}$ 591, de 06 de julho de 1992. Disponível em: $<$ http://www.planalto.gov.br/ccivil_03/decreto/1990-1994/D0591.htm>. Acesso em: 19.04.2019

BRASIL. Lei $\mathrm{n}^{\circ}$ 8.080, de 19 de setembro de 1990 (Lei do SUS). Disponível em: $<$ http://www.planalto.gov.br/ccivil_03/Leis/L8080.htm>. Acesso em: 19.04.2019.

BRASIL. Lei $\mathrm{n}^{\circ}$ 8.069, de 13 de julho de 1990 (Estatuto da Criança e do Adolescente). Disponível em:

$<$ http://www.planalto.gov.br/ccivil_03/Leis/L8069.htm>. Acesso em 19.04.2019.

BRASIL. Lei $\mathrm{n}^{\mathrm{o}}$ 10.741, de 01 de outubro de 2003 (Estatuto do Idoso). Disponível em:

$<$ http://www.planalto.gov.br/ccivil_03/LEIS/2003/L10.741.htm>. Acesso em: 19.04.2019. 
COMITÊ ESTADUAL DE SAÚDE DO RIO DE JANEIRO. Histórico do NAT. Disponível em: <http://www10.trf2.jus.br/comite-estadual-de-sauderj/nat-jus/historico/>. Acesso em 19.05.2019.

COMPARATO, Fábio Konder. A afirmação histórica dos direitos humanos/ Fábio Konder Comparato.-4a ed. rev. e atual. São Paulo: Saraiva, 2005.

COMPARATO, Fábio Konder. Ensaio sobre o juízo de constitucionalidade de políticas públicas. Revista de Informação Legislativa, Brasília, nº 138, ano 35, p. 39-48, abril/junho $1988 . \quad$ Disponível em: $<$ http://www2.senado.leg.br/bdsf/bitstream/handle/id/496870/RIL138.pdf?sequ ence $=1 \#$ page $=37$.. . Acesso em: 15.04.2019.

COMPILAÇÃO DE INSTRUMENTOS INTERNACIONAIS DE DIREITOS HUMANOS. Provedoria dos Direitos Humanos e Justiça: Primeira Edição. p. 151. Disponível em:

$<$ http://acnudh.org/wpcontent/uploads/2011/06/Compilation-ofHRinstrumentsandgeneralcomments-2009-PDHJTimor-Leste-portugues.pdf.>. Acesso em 25.04.2019.

CONSELHO NACIONAL DE JUSTIÇA, Resolução n 107, de 06 de abril de 2010. Disponível em: <http://cnj.jus.br/busca-atos-adm?documento=2831>. Acesso em 01.04.2019.

CONSELHO NACIONAL DE JUSTIÇA, Recomendação $\mathrm{n}^{0}$ 31, de 30 de março de 2010. Disponível em:

$<$ http://www.cnj.jus.br/files/atos_administrativos/recomendao-n31-30-032010-presidncia.pdf $>$. Acesso em 01.04.2019. 
CONTROLADORIA GERAL DA UNIÃO. Portal da Transparência.. Orçamento Público. Disponível em:

$<$ http://www.portaltransparencia.gov.br/entenda-a-gestao-publica/orcamentopublico.>. Acesso em 20.04.2019.

DALLARI, Sueli Gandolfi. A Construção do Direito à Saúde no Brasil. Revista de Direito Sanitário, São Paulo, v. 9, n. 3, p. 9-34, Nov. 2008/ Fev. 2009. Disponível em:

$<$ http://www.revistas.usp.br/rdisan/article/view/13128/14932>. Acesso em: 13.03.2019.

DUARTE, Vanessa Genicia. Arranjos e Diálogos Institucionais para Enfrentamento da Judicialização da Saúde: uma análise dos modelos de assessoramento técnico (NAT's). Limeira/SP. 2017. 114 p. Dissertação de Mestrado. Comissão de Pós-Graduação Interdisciplinar em Ciências Humanas e Sociais Aplicadas. Universidade Estadual de Campinas (UNICAMP).

FERRAZ, Octávio Luiz Motta; VIEIRA, Fabiola Sulpino. Direito à saúde, recursos escassos e equidade: os riscos da interpretação judicial dominante. DADOS-Revista de Ciências Sociais, Rio de Janeiro, v. 52, n. 1, p. 223-251, Mar. 2009. Disponível em:

$<\underline{\text { http://www.scielo.br/scielo.php?script=sci arttext\&pid=S0011525820090001 }}$

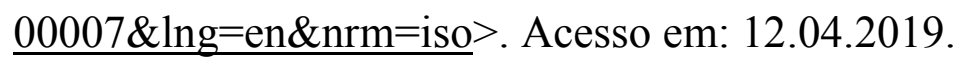

FERREIRA, Siddharta Legale; COSTA, Aline Matias da. Núcleos de Assessoria Técnica e Judicialização da Saúde: Constitucionais ou Inconstitucionais? Rev. SJRJ, Rio de Janeiro, v. 2, n. 36, p. 219-240, abr. 2013. Disponível em: $\quad<$ http://www.ufjf.br/siddharta legale/files/2014/07/Nucleos- 
de-assessoria-tecnica-e-judicializa $\% \mathrm{C} 3 \% \mathrm{~A} 7 \% \mathrm{C} 3 \% \mathrm{~A} 30$-da-

$\underline{\mathrm{sa} \% \mathrm{C} 3 \% \mathrm{BAde} . p d f>}$. Acesso em 18.05.2019.

GRAU, Eros Roberto. Planejamento econômico e regra jurídica / Eros Roberto Grau- São Paulo: Ed. Revista dos Tribunais, 1978.

HOMÉ DA CRUZ, Marco Tulio; DE NEZ, Brunna Agostini. A contribuição da mediação sanitária para a desjudicialização do direito à saúde. Seminário Internacional de Direitos Humanos e Democracia, [S.1.], dez. 2017. Disponível em: $<$ https://publicacoeseventos.unijui.edu.br/index.php/direitoshumanosedemo cracia/article/view/8658>. Acesso em: 16.05.2019.

ITÁLIA. Constituição da República Italiana, de 22 de dezembro de 1947. Disponível em:

$<$ https://www.senato.it/application/xmanager/projects/leg18/file/repository/rela zioni/libreria/novita/XVII/COST_PORTOGHESE.pdf>. Acesso em: 03.06.2018.

LABRA, Maria Eliana; FIGUEIREDO, Jorge St. Aubyn de. Associativismo, participação e cultura cívica: O potencial dos conselhos de saúde. Ciência \& Saúde Coletiva, São Paulo, v. 7, n. 3, p. 537-547, 2002. Disponível em: $<$ https://www.scielosp.org/pdf/csc/2002.v7n3/537-547/pt. $>$. Acesso em: 20.05.2019.

MACHADO, Martha de Toledo. A Proteção Constitucional de Crianças e Adolescentes e os Direitos Humanos/ Martha de Toledo Machado. Barueri, SP: Manole, 2003.

MINISTÉRIO DA SAÚDE. Resolução $\mathrm{n}^{\circ}$ 453, de 10 de maio de 2012. Disponível em: 
$<$ http://bvsms.saude.gov.br/bvs/saudelegis/cns/2012/res0453_10_05_2012.htm 1>. Acesso em: 01.04.2019.

NEPOMUCENO, M.; BELLATO, R.; ARAÚJO, L.; MUFATO, L. F. O campo jurídico na garantia do direito à saúde. Revista de Direito Sanitário, v. 14, n. 2, p. 119-136, 28 out. 2013. Disponível em:

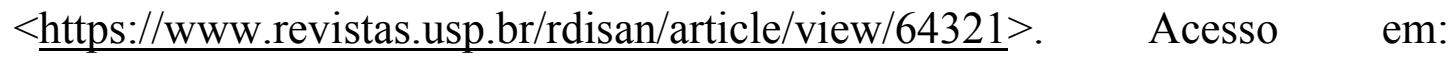
20.03.2019.

NUNES, André. A alocação equitativa inter-regional de recursos públicos federais do SUS: a receita própria do município como variável moderadora. Relatório de Consultoria (Contrato $\mathrm{n}^{\mathrm{o}}$ 130/2003) -Projeto 1.04.21. Consolidação do Sistema de Informações Sobre Orçamentos Públicos em Saúde-SIOPS. Brasília: Set. 2004. Disponível em:

$<$ http://siops.datasus.gov.br/documentacao/aloc equitativa_siops.pdf $>$. Acesso em: 12.04.2019.

OLIVEIRA, Valdir de Castro. Comunicação, informação e participação popular nos Conselhos de Saúde. Saúde soc., São Paulo, v. 13, n. 2, p. 56-69, ago. 2004. Disponível em:

$<$ http://www.scielo.br/scielo.php?script=sci arttext\&pid=S0104129020040002 $\underline{00006 \& \operatorname{lng}=\mathrm{pt \& nrm}=\mathrm{iso}>}>$. Acesso em 18.05.2019.

PINHEIRO, Mariana Carvalho. Núcleos de Assessoramento Técnico: Estratégia à judicialização da Saúde? Brasília/DF. 2016. 48 p. Monografia apresentada na Escola Nacional de Administração Pública. Disponível em: $<$ http://repositorio.enap.gov.br/bitstream/1/2490/1/Mariana\%20Pinheiro.pdf. $>$. Acesso em: 17.05.2019. 
PORTUGAL. Constituição da República Portuguesa, de 25 de abril de 1974. Disponível

em: $<$ http://www.parlamento.pt/Legislacao/Paginas/ConstituicaorepublicaPortugue sa.aspx> . Acesso em: 03.06.2018.

PRÊMIO INOVARE- Edição XI- 2014. Câmara de Resolução de Litígios de Saúde-CRLS. Descrição $\quad$ Resumida. Disponível em: $<$ https://www.premioinnovare.com.br/praticas/l/camara-de-resolucao-de litigios-de-saude-crls $>$. Acesso em: 19.05.2019.

SANTOS, Boaventura de Sousa. Democratizar a democracia: os caminhos da democracia participativa/ Boaventura de Sousa Santos, organizador. - Rio de Janeiro: Civilização Brasileira, 2002.

SARLET, Ingo Wolfang. A eficácia dos direitos fundamentais: uma teoria geral dos direitos fundamentais na perspectiva constitucional/ Ingo Wolfang Sarlet. $11^{\mathrm{a}}$ ed. rev. atual. Porto Alegre: Livraria do Advogado Editora, 2012.

SARLET, Ingo Wolfang. Algumas considerações em torno do conteúdo, eficácia e efetividade do direito à saúde na constituição de 1988. Revista Eletrônica sobre a Reforma do Estado (RERE), Salvador, Instituto Brasileiro de Direito Público, $n^{0}$ 11, setembro/outubro/novembro, 2007. Disponível em: $<$ http://www.direitodoestado.com.br/rere.asp. $>$. Acesso em: 01.04.2019.

SARLET, I.; FIGUEIREDO, M. Reserva do possível, mínimo existencial e direito à saúde. Revista Brasileira de Direitos Fundamentais \& Justiça, v. 1, n. 1, p. 171-213, 25 mar. 2007. Disponível em:

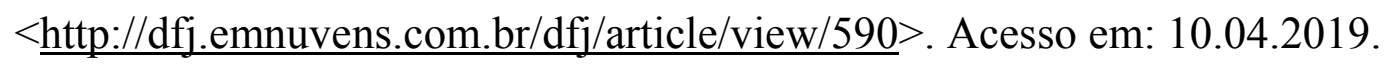


SCAFF, Fernando Facury. Reserva do possível, mínimo existencial e direitos humanos. Verba Juris, ano 4, no 4, p. 79- 104, jan./dez. 2005. Disponível em: $<$ http://periodicos.ufpb.br/index.php/vj/article/view/14814 $>$. Acesso em: 21.04.2019.

SILVA, José Afonso da. Curso de direito constitucional positivo-38 a ed. revista e atualizada. São Paulo: Malheiros Editores Ltda., 2014.

SOUZA, Anderson Monteiro de. A atuação em rede de instituições governamentais na resolução de conflitos sobre demandas sanitárias no Rio de Janeiro. Rio de Janeiro. 2016. 90 p. Dissertação Mestrado Profissional em Administração Pública - Escola Brasileira de Administração Pública e de Empresas, Fundação Getúlio Vargas - FGV. 2016. Disponível em: $<$ https://bibliotecadigital.fgv.br/dspace/bitstream/handle/10438/16052/Disserta $\% \mathrm{C} 3 \% \mathrm{~A} 7 \% \mathrm{C} 3 \% \mathrm{~A} 3 \mathrm{o}$ ver final.pdf? sequence $=1 \&$ isAllowed $=\mathrm{y} .>$. Acesso em: 16.05.2019.

SOUZA, Celina. Construção e consolidação de instituições democráticas: papel do orçamento participativo. São Paulo em Perspectiva, São Paulo, v. 15, n. 4, p. 84-97, Dez. 2001. Disponível em: $<$ http://www.scielo.br/scielo.php?script=sci arttext\&pid=S0102883920010004 $\underline{00010 \& \operatorname{lng}=\text { en\&nrm }=\text { iso }}>$. Acesso em: 25.04.2019.

STF, Despacho de Convocação da Audiência Pública de Saúde de 05 de março de 2009.2 Disponível em: $<\underline{\text { http://www.stf.jus.br/arquivo/cms/processoAudienciaPublicaSaude/anexo/De }}$ spacho_Convocatorio.pdf.>. Acesso em: 15.05.2019. 
STF, Pedido de Suspensão de Tutela Antecipada $\mathrm{n}^{\circ}$ 175, Relator Ministro Gilmar Mendes, Brasília, 17.03.2010.

$\mathrm{STF}, \mathrm{RE} \mathrm{n}^{\circ}$ 657718, Rel. Ministro Roberto Barroso, julgado em 22.05.2019 (aguarda-se publicação).

VAILlATTI, Diogo Basílio. Resenha Cidadania da Empresa e Eficácia Diagonal dos Direitos Fundamentais. (RE) PENSANDO DIREITO. CNECEdigraf. Ano 5. n. 10. jul./dez. 2015. p.237-240. Disponível em:

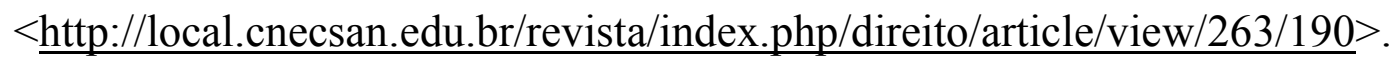
Acesso em 01.04.2019.

VIANA, Ana Luiza d'Ávila; FAUSTO, Márcia Cristina Rodrigues; LIMA, Luciana Dias de. Política de saúde e eqüidade. São Paulo Perspec., São Paulo, v. 17, n. 1, p. 58-68, Mar. 2003. Disponível em: $<$ http://www.scielo.br/scielo.php?script=sci arttext\&pid=S0102883920030001

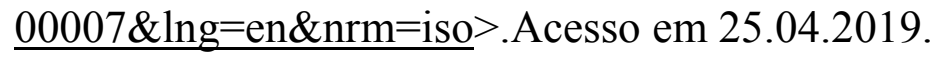

